\title{
A review of global satellite-derived snow products
}

\author{
Allan Frei ${ }^{\mathrm{a}, *}$, Marco Tedesco ${ }^{\mathrm{b}}$, Shihyan Lee ${ }^{\mathrm{c}}$, James Foster ${ }^{\mathrm{d}}$, Dorothy K. Hall ${ }^{\mathrm{d}}$, \\ Richard Kelly ${ }^{\mathrm{e}}$, David A. Robinson ${ }^{\mathrm{f}}$ \\ ${ }^{a}$ Department of Geography, Hunter College Rm. 1006N, City University of New York, 695 Park Avenue, New York, NY 10065, USA \\ ${ }^{\mathrm{b}}$ Department of Earth and Atmospheric Sciences, City College, City University of New York, NY 10031, USA \\ ${ }^{\mathrm{c}}$ Sigma Space Corporation, 4600 Forbes Blvd., Lanham, MD 20706, USA \\ ${ }^{\mathrm{d}}$ Hydrospheric and Biospheric Sciences Laboratory (Code 617.0), NASA/Goddard Space Flight Center, Greenbelt, MD 20771, USA \\ ${ }^{\mathrm{e}}$ Department of Geography \& Environmental Management, University of Waterloo, 200 University Avenue, West Waterloo, Ontario, Canada N2L $3 G 1$ \\ ${ }^{\mathrm{f}}$ Department of Geography, Rutgers University, 54 Joyce Kilmer Avenue, Piscataway, NJ 08854-8054, USA
}

\begin{abstract}
Snow cover over the Northern Hemisphere plays a crucial role in the Earth's hydrology and surface energy balance, and modulates feedbacks that control variations of global climate. While many of these variations are associated with exchanges of energy and mass between the land surface and the atmosphere, other expected changes are likely to propagate downstream and affect oceanic processes in coastal zones. For example, a large component of the freshwater flux into the Arctic Ocean comes from snow melt. The timing and magnitude of this flux affects biological and thermodynamic processes in the Arctic Ocean, and potentially across the globe through their impact on North Atlantic Deep Water formation.

Several recent global remotely sensed products provide information at unprecedented temporal, spatial, and spectral resolutions. In this article we review the theoretical underpinnings and characteristics of three key products. We also demonstrate the seasonal and spatial patterns of agreement and disagreement amongst them, and discuss current and future directions in their application and development. Though there is general agreement amongst these products, there can be disagreement over certain geographic regions and under conditions of ephemeral, patchy and melting snow.
\end{abstract}

(C) 2011 COSPAR. Published by Elsevier Ltd. All rights reserved.

Keywords: Snow; Remote sensing

\section{Introduction}

Snow covers a considerable portion of Northern Hemisphere lands during winter. It is the component of the cryosphere with the largest seasonal variation in spatial extent. In fact accumulation and rapid melt are two of the most dramatic seasonal environmental changes of any kind on the Earth's surface (Gutzler and Rosen, 1992; Robinson and Frei, 2000; Robinson et al., 1993). In the Southern Hemisphere, outside of Antarctica and its surrounding ice shelves and sea ice, snow is generally limited to smaller

\footnotetext{
* Corresponding author. Tel.: +1 212772 5322; fax: +1 2127725268 .

E-mail address: afrei@hunter.cuny.edu (A. Frei).
}

regions such as the Andes, Patagonia and the southern Alps of New Zealand (Foster et al., 2008). On decadal time scales, snow variations over Northern Hemisphere lands have also been considerable (Barry et al., 1995; Brown, 2000; Brown and Braaten, 1998; Derksen et al., 2004; Frei et al., 1999; Mote, 2006; Mote et al., 2005; Ye et al., 1998), with declines in spring associated with warmer conditions (Brown et al., 2010; Groisman et al., 1994; IPCC, 2007; Leathers and Robinson, 1993). Recent reports on changes in the Arctic environment cite snow as one of the critical variables (ACIA, 2004; AMAP, 2011). The expectation during the 21st century is that changes will be increasingly dramatic (Frei and Gong, 2005; Raisanen, 2007; Ye and Mather, 1997) and spatially and temporally complex (Brown and Mote, 2009; Nolin and Daly, 2006). 
While large scale changes in snow cover are useful as indicators of climatic variations, snow also affects other components of the Earth system at a variety of scales. By virtue of its radiative and thermal properties which modulate transfers of energy and mass at the surface-atmosphere interface (Zhang, 2005), snow affects the overlying atmosphere (Barry, 2002; Barry et al., 2007; Cohen, 1994; Ellis and Leathers, 1999; Mote, 2008; Walsh, 1984) and thereby plays an important role in the complex web of feedbacks that control local to global climate. For example, because of the high albedo of snow, its presence can change the surface energy balance over land and ice and therefore affect climate (i.e. the snow-albedo feedback). Snow also modulates the hydrologic cycle (Dyer, 2008; Graybeal and Leathers, 2006; Leathers et al., 1998; Todhunter, 2001); influences ecosystem functioning (Jones et al., 2001); and is a significant resource for many mid latitude populations and for populations whose water is derived from mountainous and northerly cold regions (Barnett et al., 2005; Barry et al., 2007). Snow observations are critical for the validation of climate models (Foster et al., 1996; Frei et al., 2003, 2005; MacKay et al., 2006; Roesch et al., 1999).

With regards to the freshwater flux to the ocean, the role of snow is to modulate seasonal timing, and in some cases the amount, of discharge into the oceans. While this can affect coastal systems across mid-latitudes, of particular relevance is the fresh water flux into the Arctic basin. The drainage area into the Arctic Ocean is $\sim 1.5$ times the surface area of the Arctic Ocean itself (Peterson et al., 2002) and river runoff is the largest source of freshwater input into the Arctic basin (Arnell, 2005; Miller and Russell, 2000). Much of Arctic precipitation is derived from snow fall, and much of the river runoff is derived from snow melt. During the past century, both high latitude precipitation (Zhang et al., 2007) and river runoff to the Arctic basin have increased; both are expected to increase further in a warming climate (Peterson et al., 2002), although the rates of change and relative impacts on ocean circulation vary spatially (Rennermalm et al., 2007).

The studies described above do not include all the possible nonlinear feedbacks in which snow plays a role in the Arctic environment (Hinzman et al., 2005). For example, due to the insulating effect of snow cover, changes in the timing of snow onset or disappearance, or changes in the amount of snow, may influence the state of the underlying permafrost, which has been warming for decades (Romanovsky et al., 2010) and which is expected to deteriorate during this century (Lawrence and Slater, 2005) and may further increase the freshwater flux. Thawing permafrost may also result in a significant release of carbon to the atmosphere as the result of microbial decomposition of currently frozen organic carbon (Schuur et al., 2008). According to Betts (2000) the expected expansion of the boreal forest may lead to both negative feedbacks (an additional carbon sink) and positive feedbacks (an albedo decrease) on global climate, and the net effect will be a positive feedback with increased warming. The feedbacks between snow, permafrost, and freshwater flux to the Arctic Ocean associated with these processes are poorly understood (Francis et al., 2009; Rawlins et al., 2010).

While an increased freshwater flux to the Arctic has potential effects on thermodynamic and ecological processes in the coastal zone, perhaps most importantly such increases have been shown in the past to diminish or completely halt the formation of North Atlantic Deep Water (NADW) (Rahmstorf, 2000). This occurs because freshwater export to the North Atlantic Ocean, the region of NADW formation, decreases surface water density. Model simulations suggest that the magnitude of expected runoff changes during this century may approach critical thresholds for NADW formation (Arnell, 2005; Miller and Russell, 2000; Peterson et al., 2002). In a recent study, NADW formation as well as permafrost degradation and changes to the tundra and boreal forest ecosystems (all of which can be affected by snow, and all of which can affect the freshwater flux to the ocean) have been listed among the potentially critical components of the Earth system that may be in danger of approaching "tipping points" (Lenton et al., 2008). Thus, accurate monitoring of high latitude snow remains an essential goal.

Because of the large extent of terrestrial snow cover and the difficulties in obtaining ground measurements over cold regions, remote sensing represents an important tool for studying snow properties at regional to global scales. In recent years, advances in satellite capabilities, as well as in algorithm development, have led to improved monitoring of snow across the globe. The purpose of this article is to review the current generation of satellite-derived global snow observations that has become available during the first decade of the twenty first century, with emphasis on land surfaces of the Northern Hemisphere. Theoretical considerations for the remote sensing of snow, and key products are discussed.

\section{Theoretical background}

Due to the nature of interactions between snow cover and electromagnetic radiation of different frequencies, snow can be distinguished from other terrestrial surfaces using satellite observations based on a number of different active and passive techniques (Dozier, 1989; Nolin, 2010). The two types of instruments used for monitoring global scale snow variations rely on either (1) a combination of the visible and infrared, or (2) microwave, portions of the electromagnetic spectrum (Hall et al., 2005; Matzler, 1994; Rango et al., 2000; Scherer et al., 2005; Schmugge et al., 2002). These methods are limited by a number of factors, such as clouds, forest cover fraction, terrain heterogeneity and precipitation. For example, interpretation of visible and infrared as well as passive microwave images can be difficult where complex terrain causes considerable spatial variation within each remotely-sensed footprint of snow depth, surface characteristics, and satellite viewing angles. Nevertheless, products based on these observations 
have been vital for monitoring snow and for our understanding of the role of snow in the Earth system. Though global active microwave data (e.g., QuikSCAT) can also be used to study snow extent and depth at relatively large spatial scale (Tedesco and Miller, 2007a,b), data are available only from 1999 to 2009 (when the satellite failed well past its expected lifetime; see http://www.jpl.nasa.gov/ news/news.cfm?release $=2009-175$ downloaded November 2011). In contrast, passive microwave data have been available since the late 1970s, and continue to be available. At regional scales, airborne data can also be collected before and after the snow falls to study the attenuation introduced by the snow pack on naturally emitted gamma radiation (Carroll, 1987). However, the data collected with this method have low temporal resolution (seasonal scale) and cannot be used for global scale studies. Consequently, we focus our analysis on snow parameters estimated by means of visible and infrared and passive microwave sensors.

\subsection{Visible and near-infrared}

Snow extent (i.e. presence or absence of snow, regardless of snow amount) is, in many circumstances, relatively straightforward to observe using visible observations because of the high albedo of snow (up to $\sim 80 \%$ or more in the visible part of the electromagnetic spectrum) relative to most land surfaces. However, limitations exist. First, visible imagery is limited to that portion of the surface illuminated by sunlight; thus darkness and low illumination are problematic. Second, clouds impede visible evaluation in two ways. All but the thinnest clouds reflect a significant portion of visible radiation, preventing any visible radiative information about the surface from reaching the satellite. And, because the albedos of clouds and snow are often similar, the discrimination between cloud-covered and snow covered surfaces can be difficult. However, near-infrared bands can be used to distinguish between snow and most clouds because the near-infrared reflectance of most clouds is high while the near-infrared reflectance of snow is low.

Third, vegetation can obstruct visible and infrared information about snow from reaching the satellite sensor. Forest canopies protrude above the snow pack, lowering the surface albedo (Robinson and Kukla, 1985) and partially or completely obscuring the underlying surface, making it difficult to determine snow extent or amount (Chang et al., 1996; Derksen, 2008; Goita et al., 2003; Klein et al., 1998; Nolin, 2004).

Lastly, surface heterogeneity can play a role the interpretation of visible and infrared imagery in a number of ways. Of particular relevance to the monitoring of high latitude snow is the presence of numerous frozen lakes in Arctic regions, which may contribute to the overestimation of snow covered area from visible and infrared based imagery during periods when lakes remain frozen after the snow has melted on adjacent land surfaces (Derksen et al., 2005a; Frei and Lee, 2010), at least when high resolution land surface data sets are not used to filter out the signal from lake surfaces. Passive microwave based estimates of SWE may be underestimated due to the presence of lakes (Derksen et al., 2005a; Rees et al., 2006). On the other hand, surface heterogeneity may assist in the interpretation of snow-covered versus snow-free ground, and of snow-covered versus cloud-covered scenes, when trained analysts are mapping snow extent using visible imagery.

\subsection{Passive microwave}

Because snow grain dimensions can be similar to microwave wavelengths, snow is efficient at scattering the microwave radiation naturally emitted from the Earth's surface (Matzler, 1994). Therefore, microwave emission from a snow covered surface is diminished relative to a snow-free surface, and the presence of snow can frequently be identified (Chang et al., 1976; Grody, 2008; Hall et al., 2005; Matzler, 1994; Tait, 1998; Tedesco and Kim, 2006). Furthermore, because under ideal circumstances the amount of scattering is proportional to the number of snow grains, microwave instruments offer the possibility of estimating the mass per unit area of water in the snow pack, which is often measured as snow water equivalent (SWE). In contrast to visible and infrared, passive microwave does not depend on the presence of sunlight and thus provides an alternative at high latitudes; and, passive microwave is largely (but not completely) transmitted through non-precipitating clouds, offering the potential to estimate snow cover under many cloudy conditions that preclude visible and infrared observations. In practice, research using passive microwave exploits the fact that microwave scattering by ice crystals is frequency-dependent: higher frequencies within the microwave portion of the spectrum are scattered more efficiently than lower frequencies, enabling the use of two or more frequency bands to estimate SWE (Chang et al., 1987; Derksen, 2008; Derksen et al., 2005b; Grody and Basist, 1996). Other methods have also been evaluated such as one based on the inversion of a snow emission model (e.g., Pulliainen and Hallikainen, 2001). Clifford (2010) provides a review of global estimates of snow water equivalent from passive microwave.

Limitations to the monitoring of snow using passive microwave sensors are due to a variety of factors. One major limitation is the presence of liquid water in the snow pack, the microwave emission from which masks the snow signal and inhibits the ability of microwave sensors to detect wet snow. Also, because of the relatively weak microwave signal emitted by terrestrial surfaces, microwave sensor footprints are necessarily large $(\sim 25 \mathrm{~km})$. Uncertainties in snow depth and SWE estimates are associated with the physical structure of snow packs (ice lenses, grain size variations and vertical heterogeneity) which vary in space (Chang et al., 1976; Sturm et al., 1995) and time (Langham, 1981) and can alter the scattering and emission characteristics of the snow pack. Snow pack metamorphosis, which in the Arctic region typically results in a layer of depth hoar (with large crystal size) near the bottom of the 
pack, results in more efficient microwave scattering. Thus, a signal change measured at the satellite sensor due to snow metamorphosis can mimic a signal change due to a change in SWE. Vegetation in and above the snow pack emits microwave radiation, and can confound any detection algorithm (Chang et al., 1996; Foster et al., 1997; Tedesco et al., 2005).

Finally, as a snow pack reaches a certain critical depth the relationship between snow-amount and MW brightness temperature reverses (Derksen, 2008; Markus et al., 2006; Matzler, 1994; Schanda et al., 1983). When SWE exceeds $\sim 150 \mathrm{~mm}$ emission by the snow pack of microwave band radiation is greater than scattering, resulting in a positive relationship between SWE and brightness temperature. This is an additional source of uncertainty in SWE retrievals for deep snow packs.

\subsection{Remote sensing of snow in complex terrain}

Some of the difficulties inherent in the interpretation of remotely sensed images are exacerbated in regions with complex terrain (Dozier, 1989). Due to variability of slope, aspect, and land cover, the local solar illumination angle varies within one satellite footprint. In fact, due to co-registration differences between an image and a digital elevation model, illumination angles, and therefore reflectance characteristics, are often unknown. To address such issues, Painter et al. (2009) developed the MODSCAG model, which estimates mean grain size and fractional snow cover from MODIS data using linear spectral mixture analysis and a library of reflectance characteristics of different surface types. This model has relatively small errors, and could potentially be applied globally, but so far has been validated mostly in regions of complex terrain.

A recent study of different algorithms for estimating SWE from passive microwave radiances in a basin with complex terrain in the Canadian Rockies finds that the traditional algorithms which are based on brightness temperature differences in difference wavelength intervals (as discussed above) are less accurate than Artificial Neural Network (ANN) techniques which can be trained on observations from surface stations (Tong et al., 2010a). Unfortunately, due to the limited distribution of stations for training the ANN in their test region, they are unable to accurately estimate spatial variations of SWE. Tong and Velicogna (2010) and Tong et al. (2010b), using surface station observations and MODIS imagery across the Mackenzie River Basin, determine that the minimum or threshold SWE value estimated from passive microwave observations that can be used to determine the presence/absence of snow varies from sub-basin to sub-basin, depending on topography and vegetation cover. Nevertheless they find useful information in remotely sensed SWE values for hydrologic monitoring. As these studies indicate, the estimation of snow characteristics in complex terrain from remotely sensed imagery is an important and cutting edge field of study. At this time, these techniques have not been incor- porated into global products, and are not addressed further in this paper.

\subsection{Comparison and evaluation of products}

When two products disagree, which is "correct?" Is either one of them "correct?" Two key impediments to a conclusive evaluation are that there is no perfect "ground truth," and that the answer depends on spatial scale. The most obvious method of testing the veracity of remotely sensed (or other gridded) products is by comparison to surface reference observations. However, there exists considerable contrast between surface, or in situ, and remote snow observations with regards to the snow pack properties that can be measured, their spatial and temporal resolutions and domains, and the methods employed to make measurements (Brown and Armstrong, 2008; Goodison et al., 1981).

Even in regions with surface observations, validation may be difficult because of the contrasting spatial scales of surface and remotely sensed observations (Brubaker et al., 2005; Chang et al., 2005). Brubaker et al. (2005) discuss the difficulties in comparing point measurements to spatially integrated satellite retrievals, especially in areas of sparse station networks, which are typically at high elevations and northerly regions (exactly the areas where snow is most prevalent). They find that there is no single accepted method to perform validation of remotely sensed snow products. Chang et al. (2005) provide an informative review of how varying station densities and different satellite footprints are not equally spatially representative, and how the differences can complicate evaluations and comparisons of different products. They employ geostatistical techniques, as suggested by Kelly et al. (2004), to quantitatively define the spatial density of station observations required to provide sufficient information for validation studies. MODIS has been found to compare well with station based observations as well as with the National Operational Hydrologic Remote Sensing Center products (Hall and Riggs, 2007), but Riggs et al. (2005) show that even between different versions of MODIS snow products, analyses at different spatial resolutions can provide conflicting results in some cases, due to both the resolution differences and the averaging method.

Despite the inherent difficulties, comparative studies to date have drawn some useful conclusions (Armstrong and Brodzik, 2001; Basist et al., 1996; Bitner et al., 2002; Brown et al., 2007, 2010; Derksen et al., 2003; Drusch et al., 2004; Foster et al., 1997; Mialon et al., 2005; Mote et al., 2003; Romanov et al., 2002; Savoie et al., 2007; Tait and Armstrong, 1996). For example, evaluations of NOAA visible and infrared versus passive microwave products find more disagreement during fall and spring than during midwinter, with particular differences under forest canopies, over complex terrain, in areas of persistent clouds, patchy snow, and wet snow (Armstrong and Brodzik, 2001; Basist et al., 1996). Over the Tibetan Plateau these products often 
disagree year-round (Armstrong and Brodzik, 2001; Savoie et al., 2007). Several recent studies identify differences between remotely sensed products and surface observations over North America during the spring ablation season (Brown et al., 2007, 2010; Frei and Lee, 2010).

\section{Snow products}

A number of digital products that are based on remote observations are available. The two visible and infrared based suites of products that are most widely used for large-scale climate research are from: (1) the Interactive Multisensor Snow and Ice Mapping System (IMS) (Section 3.1) and (2) the suite of products derived from the Moderate Resolution Imaging Spectroradiometer (MODIS) (Section 3.2). IMS is the most recent version of a product that dates back to the 1960s (Matson and Wiesnet, 1981). IMS mapping of snow extent has relied primarily on visible and near infrared imagery, but includes data and information from a number of sources. As discussed in more detail below, the key feature that distinguishes IMS from other products is human involvement in the analysis, which is required for operational purposes.

The MODIS instrument, which is used to observe a number of geophysical variables including snow, flies on NASA's Earth Observing System (EOS) Terra satellite, launched in 1999. A near-twin MODIS instrument is also flying on board the Aqua platform, which was launched in 2002 (Aqua and Terra have afternoon and morning equatorial crossing times, respectively). Aqua also hosted the Advanced Microwave Scanning Radiometer - Earth Observing System (AMSR-E) until its failure in October 2011. AMSR-E measured the naturally emitted radiation in the microwave region at five different frequencies (6.9, $10.7,18.7,23.8,36.5$ and $89 \mathrm{GHz}$ ) at both vertical and horizontal polarizations.

The IMS and MODIS snow algorithms both rely primarily on near-polar orbiting satellites, from which daily images are available at high latitudes. Other algorithms that have been suggested (Romanov et al., 2003; Siljamo and Hyvarinen, 2011) rely on geostationary satellites, which have the advantage of higher temporal resolution, but have poor spatial resolution.

\section{1. visible and near infrared based products}

\subsubsection{The Interactive Multisensor Snow and Ice Mapping System (IMS)}

The data set that has historically been the most widely used for the operational mapping and climatological analysis of large-scale snow extent (not depth or water equivalent) was produced by the US National Oceanic and Atmospheric Administration (NOAA) National Environmental Satellite and Data Information Service (NESDIS), but has been transferred to the National Ice Center (NIC), which is jointly supported by NOAA, the US Navy, and the US Coast Guard. This product has been based pri- marily on visible and near infrared observations, and covers the period from late 1998 to present (Ramsay, 1998), with the precursor maps beginning in 1966, constituting the longest remotely sensed environmental time series that has been derived in a near-consistent fashion (Helfrich et al., 2007; Matson and Wiesnet, 1981; Robinson et al., 1993). The term near-consistent is used because, due to changing operational requirements and evolving technical capabilities, this product has undergone, and continues to undergo, improvements and refinements (Helfrich et al., 2007; Ramsay, 1998, 2000) as summarized briefly here. The two reasons for this product's importance - as operational input into atmospheric forecast models and as a long-term climatic record - are also discussed.

Although a number of improvements and corrections in the production of the NOAA product occurred in the earlier years, the biggest methodological change was implemented in the late 1990s. Until that time, NOAA snow maps were produced on a weekly basis by trained meteorologists who would visually interpret photographic copies of visible band imagery, and manually produce maps that would subsequently be digitized with spatial resolution between $150 \mathrm{~km}$ and $200 \mathrm{~km}$. In 1997 NOAA began producing snow maps using the IMS, with improved spatial $(24 \mathrm{~km})$ and temporal (daily) resolutions. IMS is operated by trained analysts who produce a daily digital product utilizing Geographic Information System technology and incorporating a variety of, and an ongoing expansion of, technological capabilities as well as sources of information. Since 1999, when weekly manual mapping was discontinued, daily IMS maps have been produced (Ramsay, 1998; Robinson et al., 1999). Technological advancements since 1999 have led to even higher resolution $(4 \mathrm{~km})$ snow mapping (Helfrich et al., 2007).

IMS produces estimates of snow extent across the globe every day, regardless of the presence of clouds. This is possible primarily for two reasons. First, analysts use sources of information other than visible and near infrared imagery. Second, because IMS analysts can loop through sequential images, their ability to evaluate scenes is based on an integration of information from both spatial and temporal perspectives. Thus, a key feature of the IMS product is that human judgment as to which data sources are most reliable in different conditions and regions, and as to the final evaluation of where the snow is, remains an integral part of the process, and one of the strengths of the IMS product. IMS also includes sea ice extent, which is not discussed in this report. Fig. 1 shows an example of a daily IMS snow map in its original projection.

It is difficult to optimize this product for both of its two main uses. Its primary purpose is to provide input to atmospheric forecast models. For this purpose, continued product improvements are advantageous. As a record for evaluating long term environmental change, however, the value of any product is diminished if methodological changes (including those that provide more accurate maps) result in temporal inconsistencies in the data set that might 


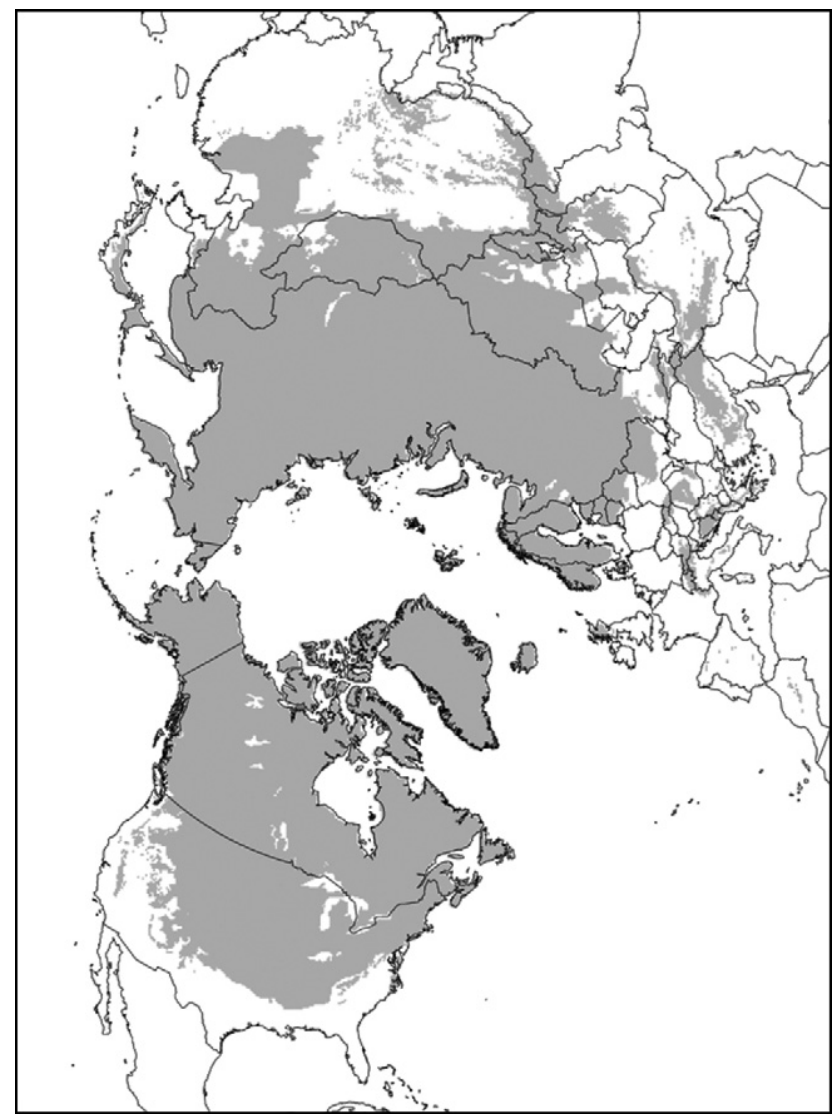

Fig. 1. Snow extent on February 10, 2011, obtained from IMS.

be difficult to distinguish from actual variations in snow extent. To maintain product continuity and a viable longterm record, IMS continues to produce a coarse $(24 \mathrm{~km})$ resolution version of the data set. And, in collaboration with NOAA, the Rutgers University Global Snow Lab is producing a climate data record in which inconsistencies between the earlier maps and the IMS product (in addition to inconsistencies during the weekly map era) are accounted for, and can therefore be used for ongoing analyses of historical variations (Robinson and Estilow, 2008).

\subsubsection{The Moderate Resolution Imaging Spectroradiometer (MODIS)}

The MODIS sensor measures radiation in 36 spectral bands, including the visible, near infrared, and infrared parts of the electromagnetic spectrum. The suite of MODIS snow cover products, available since 2000, are derived using a fully-automated algorithm that provides good spatial resolution $(500 \mathrm{~m})$, cloud detection, and frequent coverage (daily at mid to high latitudes) (Hall and Riggs, 2007; Hall et al., 1995, 2002; Riggs et al., 2006). The MODIS snow-mapping algorithm uses a normalized difference between MODIS band $4(5.45-5.65 \mathrm{~mm})$ and 6 $(1.628-1.652 \mu \mathrm{m})$ and many additional spectral and threshold tests. In forested areas the threshold is changed based on results of a canopy reflectance model, using both the Normalized Difference Vegetation Index (NDVI) and
Normalized Difference Snow Index (NDSI) (Klein et al., 1998). A thermal mask is also included to remove erroneous "snow" over locations where the presence of snow is considered to be implausible. See Riggs et al. (2006) and Riggs and Hall (in press) for a description of the algorithm and recent upgrades.

NASA provides a hierarchy of snow products based on MODIS observations, designed to satisfy the needs of a variety of users (http://modis-snow-ice.gsfc.nasa.gov/). These include a Level-2 swath product; daily and 8-day composite Level-3 tile products which are mapped onto a sinusoidal projection and available in $10^{\circ}$ lat/lon tiles; as well as daily, 8-day composite, and monthly Level-3 products available in the Climate-Modeling Grid (a latitude-longitude grid) at $0.05^{\circ}$ resolution (Hall et al., 2002, 2005; Riggs et al., 2005, 2006). An 8-day composite is considered useful because in many regions, particularly at high latitudes, persistent cloudiness limits the number of days available for surface observations (see results section). The Climate-Modeling Grid was developed to be useful for the evaluation of climate models and for studies at large spatial scales. Other features of the MODIS snow product suite include daily snow albedo (Klein and Stroeve, 2002) and fractional snow cover (Salomonson and Appel, 2004). In addition, a new cloud-gap filled product provides information on cloud persistence, and uses observations from prior days to map snow (Hall et al., 2010). Fig. 2 shows examples of MODIS snow cover maps in swath format (MOD10_L2) following a major snowstorm in the northeastern United States in December 2010. The analysis presented in Sections 4 And 5 of this article uses the MOD10C1 daily Level 3 global $.05^{\circ}$ daily ClimateModeling Grid product with a spatial resolution of $\sim 5 \mathrm{~km}$.

Validation of the suite of MODIS snow cover products has been undertaken by many authors as described in Hall and Riggs (2007). These products have also been used extensively in modeling efforts, both at the regional and hemispheric scales. A bibliography of papers utilizing the MODIS snow cover products for both validation and modeling may be found at: http://modis-snow-ice.gsfc.nasa.gov/?c=publications.

\subsection{Passive microwave based products}

Historical passive microwave measurements are available from the Scanning Multichannel Microwave Radiometer (SMMR) instrument (1978-1987), and the Special Sensor Microwave/Imager (SSM/I) instrument (1987 through present) although some compatibility issues between the two products exist, due to slight differences in the frequency bands measured, overpass time, swath width, native footprint resolution, and coverage issues related to SMMR being powered down every other day. (Armstrong and Brodzik, 2001; Brodzik et al., 2007; Derksen and Walker, 2003). AMSR-E, available from 2002 to October 2011, provides a suite of measurements to make it spectrally 

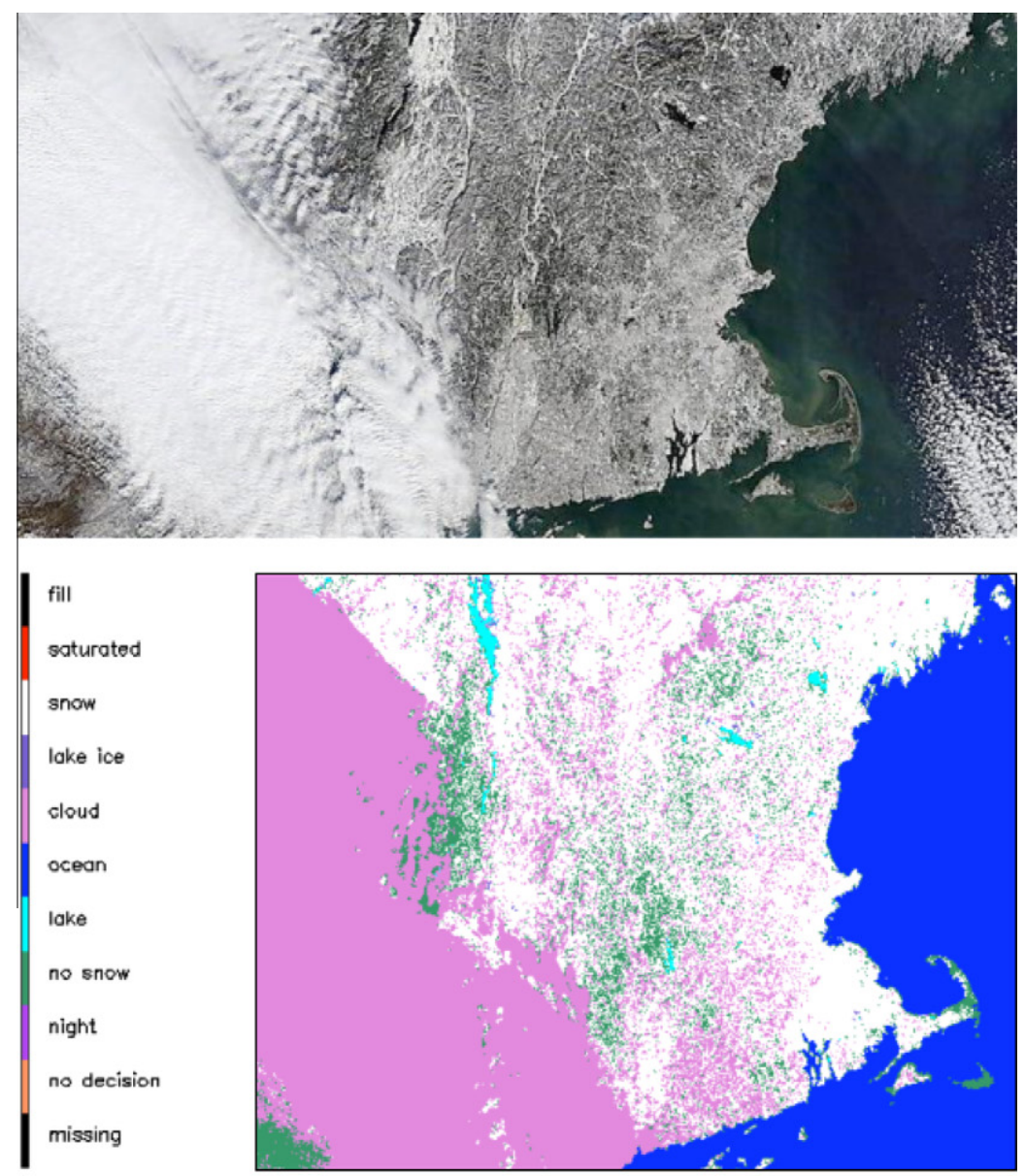

\begin{tabular}{|l} 
fill \\
saturated \\
cloud \\
water \\
$91-100$ \\
$81-90$ \\
$71-80$ \\
$61-70$
\end{tabular}

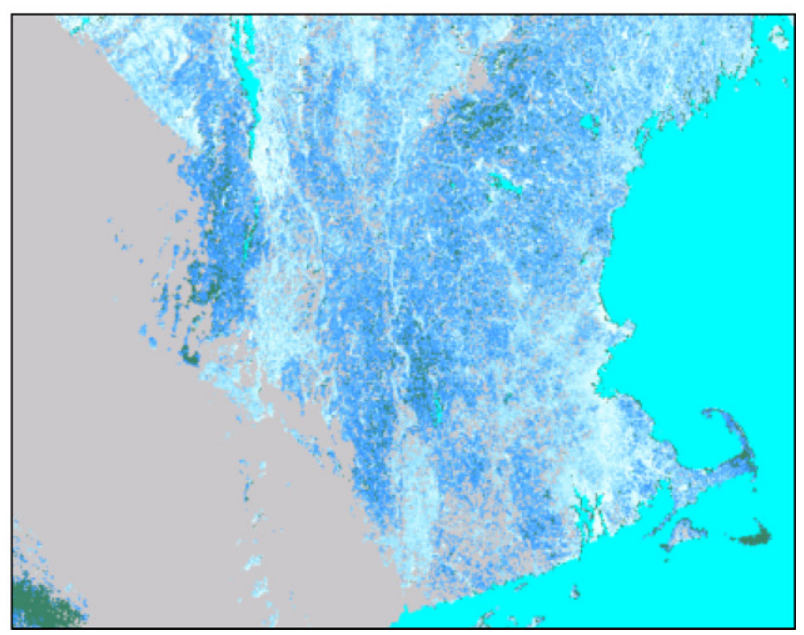

Fig. 2. Images acquired on 28 December 2010 showing extensive snow cover as the result of a major snowstorm in the northeastern United States on $26-$ 27 December. The image on top is a "true-color" image from the MOD09 reflectance product; the center image is a binary MOD10_L2 swath snow map; and the image on the bottom represents fractional snow cover from MOD10_L2, so that various shades of blue indicate different fractions of snow cover within each pixel. Image processing by Jeff Miller, Wylie Systems, and NASA/GSFC.

compatible with both SMMR and SSM/I at higher spatial resolution (Derksen et al., 2005b; Kelly et al., 2004). Due to the inherent difficulties and regional variations in the interpretation of passive microwave signals, the production of a data set that is consistently accurate across all Northern Hemisphere regions requires either (1) a physical approach, which includes robust representations of snow pack pro- cesses and their parameterization in retrieval schemes (Pulliainen and Hallikainen, 2001), or (2) a regional approach, which includes regionally-tuned algorithms (Foster et al., 1997) that statistically represent regional snow pack processes but which are not applicable in different snow accumulation regimes. The physical approach is very challenging yet has the potential of being widely applicable 
as our knowledge of, and ability to model, regional snow pack processes improves, while the statistical approach is applicable only in the few regions for which retrieval schemes have been calibrated.

The global AMSR-E SWE product suite (Tedesco et al., 2011 updated) consists of daily, pentad (five-day) maximum and monthly average SWE estimates that together comprise the only NASA satellite-based SWE product available to the scientific community. As an example, Fig. 3 shows the snow depth obtained from the AMSR-E product for January 30th, 2005.

The AMSR-E SWE operational algorithm takes advantage of several AMSR-E channels that are unavailable from SSM/I and SMMR. Snow depth is derived as a combination of microwave brightness temperature differences at different frequencies, weighted by coefficients derived from the difference between vertical and horizontal polarizations. These coefficients replaced a previously used static coefficient to attempt to capture the spatio-temporal variability of parameters such as grain size (Kelly, 2009; Kelly et al., 2003; Tedesco and Narvekar, 2010). The algorithm uses a spatially varying but temporally static map of snow density.

Environment Canada (http://ccin.ca/cms/en/socc/snow/ swe/currentSnow.aspx) also produces a regional passive microwave SWE product for central Canada, including the Prairies and part of the boreal forest back to 1978. Until December 1999, this product relied on a single algo-

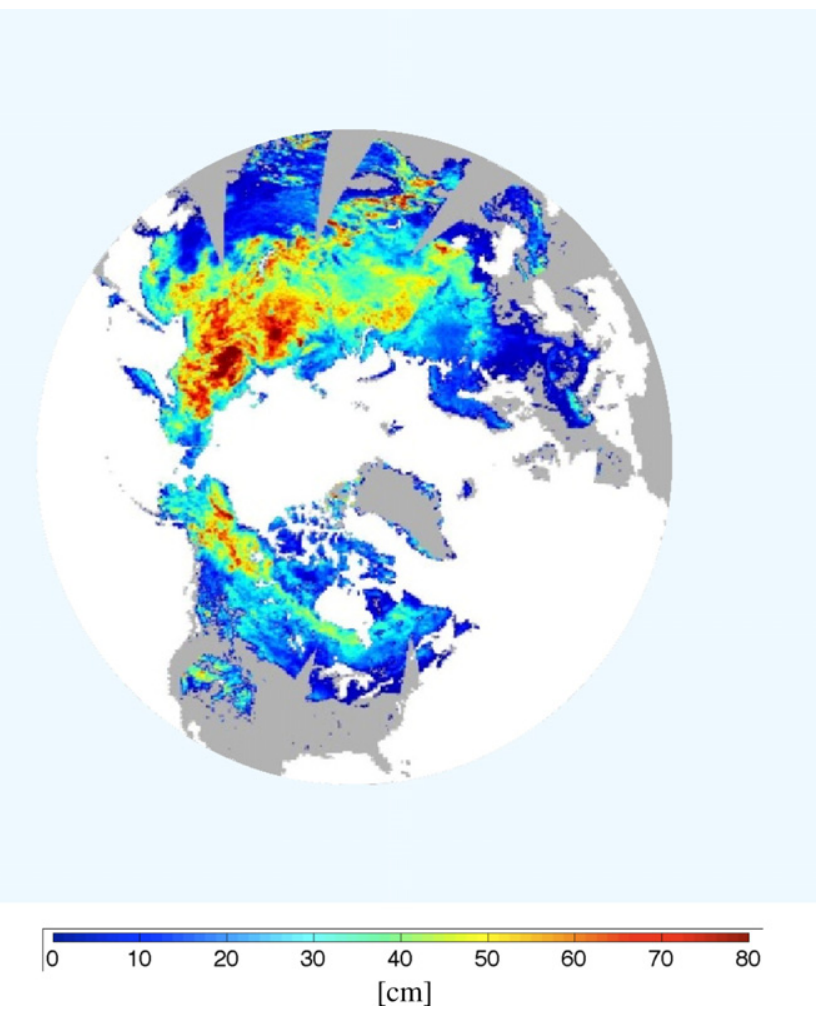

Fig. 3. Snow depth on January 30, 2005 obtained from the AMSR-E product. rithm that was calibrated for the prairies region (Goodison and Walker, 1995). Since that time algorithms that correct for the effects of different forest types (Derksen, 2008; Goita et al., 2003) and the sub-Arctic tundra (Derksen et al., 2010) have been developed.

\subsection{Combined products}

One promising avenue, and an area where great efforts are currently being made, is to refine our abilities to combine ground observations and models with space borne remotely sensed data. Tait et al. (2000) provide a helpful review, and describe a prototype of a fully automated product that includes station observations as well as both visible and microwave retrievals. Here we briefly review some products that include combinations of satellite, station observations, and models. While not exhaustive, it provides examples of the variety of integrative products and methods that have been produced.

\subsubsection{The Canadian Meteorological Center snow product (station observations and modeling)}

Snow depth from the Canadian Meteorological Center Daily Snow Depth Analysis includes a hybrid modeling/ observational approach based on optimal-interpolation of daily snow depth observations from hundreds of stations globally, with snow density estimated from a simple snow pack model (Brasnett, 1999). This model output is considered most dependable over regions with significant station coverage, which is generally south of $55^{\circ}$ North, where model results are well constrained by observations. Over most of the Arctic, in contrast, where there are few observations, the analysis is based mostly on model results, and is skewed towards snow depth observations at coastal locations with observing sites at open areas near airports. Snow at these sites tends to be shallower and to melt out earlier than snow in surrounding terrain. Nevertheless, this analysis is considered to be a reasonable estimate of snow depth over data-poor Arctic regions, and has been used in a number of studies (Brown and Mote, 2009). Here we use CMC modeled snow depths for comparison with AMSR-E snow depths.

\subsubsection{GlobSnow (satellite, station, and model)}

In 2008 the European Space Agency embarked on an effort to develop a long term snow cover data set called GlobSnow with sufficient homogeneity to be acceptable for climate change analysis. The GlobSnow product currently includes global gridded information on snow extent and SWE across the Northern Hemisphere (excluding mountainous regions) (Pulliainen, 2010). The SWE product is based on the method of Pulliainen (2006). By incorporating station observations and snow pack modeling into passive microwave retrieval algorithms, the goal is to provide an accurate product useful for analyses at many different spatial scales, and for near-real time as well as climatological studies. The snow extent product is created 
using European Space Agency satellite visible and infrared observations (ERS-2 ATSR-2 and Envisat AATSR) based on the method of Metsamaki et al. (2005), and will likely be available at a variety of spatial resolutions. GlobSnow is currently available (http://www.globsnow.info/) but is new, so there is little peer-reviewed literature on it at the time of this writing (Takala et al., 2011).

\subsubsection{Other combined products}

A variety of combined products have been produced globally, regionally, or for specific purposes. One widely used combined product is NOAA's National Operational Hydrologic Remote Sensing Center Snow Data Assimilation System, which operationally incorporates input from snow models, station reports, and airborne sensors to estimate daily SWE at $1 \mathrm{~km}$ resolution across the continental US (Carroll et al., 2001). The product by Brown et al. (2003), which employs the operational snow depth routine of the Canadian Meterological Center model (Brasnett, 1999), has been used for evaluation of climate models (Frei et al., 2005). Foster et al. (2008) recently produced a global product blending visible and infrared, passive microwave, and active microwave scatterometer data, with the intention of incorporating the most reliable aspects of each product. Derksen et al. (2004) produced a product going back to the early 20th century for the North American Prairies and Great Plains based on passive microwave and station observations. Biancamaria et al. (2011) estimated Northern Hemisphere fields of SWE based on passive microwave combined with a dynamic snow grain model. Grundstein et al. (2002) developed a research-oriented SWE climatology for the Great Plains of the United States by combining station observations with the 1-dimensional snow pack model SNTHERM (Jordan, 1991). A research-oriented product based on spatial interpolation of in situ depth measurements over North America (Dyer and Mote, 2006) has been used for process studies (Ge and Gong, 2008). The QuickSCAT active microwave scatterometer has been used to estimate the timing of snow melt across Greenland (Nghiem et al., 2001) and across Arctic lands (Wang et al., 2008).

\section{Methodology to compare and contrast products}

In this section we describe the methodology that we use to demonstrate the regions over which the products typically differ. This analysis is not meant to provide insight into new remote sensing techniques, but rather to demonstrate the spatial extents and magnitudes of the differences between products during different seasons. The methodology employed here is designed to achieve two goals: (1) to identify regions across the Northern Hemisphere where there is agreement/disagreement between the three main products discussed here during clear days; and (2) to provide an indication of the spatial distribution of uncertainty in the AMSR-E snow depth estimates, as determined by comparison to the CMC product. In this report we show results for three months: October (a month of rapid average increase of snow area), January (the month of largest average snow area), and April (a month of rapid average decrease of snow area). For our analysis, AMSR-E SWE values are converted to depth. This is done using a fixed density mask, which is also used as part of the standard product algorithm to estimate SWE values. We reverse the process in order to convert SWE values to depth. The reprojection methods, and the methods for each goal, are discussed in more detail in Sections 4.1-4.3.

Many of our methods for goal 1 closely follow Frei and Lee (2010), and the reader is referred to that article for more details and justification of the methods. Note that, without independent verification, agreement between products does not guarantee that they are correct; and, that if two of the three products agree, it does not guarantee that the third product is incorrect.

\subsection{Reprojection procedure}

IMS and MOD10C1 data sets were reprojected to the EASE-Grid $25 \mathrm{~km}$ projection (Brodzik and Knowles, 2002) (AMSR-E is already in this projection). Each EASE-Grid cell value was calculated as a binary (i.e. snow or no-snow) value. Because reprojection can introduce spurious errors at the grid-cell scale, and these errors are likely to be exacerbated in areas of variable terrain, we show no results for EASE-Grid cells within which the GTOPO 30 DEM elevation field has a standard deviation $>100 \mathrm{~m}$. We also avoid drawing conclusions from individual grid points, but rather focus on results over large regions with relatively little topographic variation. The reprojection, binary snow value calculation, and terrain masking were performed according to the method of Frei and Lee (2010).

\subsection{Agreement/disagreement between IMS, MODIS, and AMSR-E snow extent}

Since both IMS and MOD10C1 provide binary values indicating either the presence or absence of snow (the standard MODIS products also provide fractional snow cover) but not snow depth, AMSR-E snow depths were converted to a binary value to facilitate this comparison. All AMSRE depth estimates below $5 \mathrm{~cm}$ are considered snow free as that is the depth value assigned to shallow snow.

All snow extent analyses include, at each grid cell, only days with "clear" skies, and only days for which all three products have non-missing data. We use the MOD10C1 cloud mask to identify EASE-Grid cells that are mostly clear. Because MOD10C1 0.05 degree cells are higher resolution than the EASE-Grid and include fractional cloud cover, they can be used to estimate fractional cloud cover within each grid cell of our analysis. And, because the MOD10C1 cloud mask is considered conservative (in the sense that cloud-covered scenes are unlikely to be designated as "clear") (Riggs and Hall, 2002), we feel confident 
that information from cloudy days is not being retained for analysis. This is achieved by retaining for analysis, for each EASE-Grid cell, only days with $>80 \%$ of MOD $10 \mathrm{C} 1$ cells that are $<20 \%$ cloud covered, for which no product is missing data. Frei and Lee (2010) present the rationale for this method and explain how the results are insensitive to reasonable values of these parameters. For each grid point on each day, either all three products agree (i.e. either snow or no-snow), or one product differs from the other two. The figures summarizing our results show, for each month, where each product disagrees with the other two products.

\subsection{Comparison of AMSR-E and Canadian Meteorological Centre (CMC) snow products}

For passive microwave data and the CMC model, no cloud mask is invoked, so we retain for analysis all available dates. While passive microwave data are not limited by most clouds, clouds with high liquid water content can affect the comparison between spaceborne- and groundbased SWE estimates (Wang and Tedesco, 2007); this issue is ignored here in order to increase the sample size.

The comparison of AMSR-E to the CMC snow product is done by comparing climatological maps (2003-2010). For each month, three panels are shown containing maps of AMSR-E snow depth, CMC snow depth, and the difference between the two products (we calculate the difference as CMC minus AMSR-E, so that a negative difference indicates that AMSR-E overestimates snow depth with respect to $\mathrm{CMC}$ ).

\section{Results}

In this section we show the results of our analysis, the purpose of which is to demonstrate the spatial patterns of disagreement between the data sets. We also discuss possible reasons for disagreements. In some cases these reasons may be speculative.

\subsection{Number of days per month available for analysis}

Before discussing disagreements between the products, we first show maps of the number of days per month available for comparison (Fig. 4) which demonstrate the problem presented by clouds. During October and January (Fig. 4a and b) most Arctic land surfaces are colored green ${ }^{1}$ or dark blue, which indicates that on average less than three (green) or three to six (dark blue) days per month are available for analysis. (In January one also sees the "ring" around the Arctic with no data associated with no solar illumination.) During spring, which tends to be less cloudy over most regions (Fig. 4c), one can find large por-

\footnotetext{
${ }^{1}$ For interpretation of color in Fig. 4, the reader is referred to the web version of this article.
}

tions of the Arctic with either six to nine or nine to 12 days per month available for comparison.

The vast majority of the unavailable days are caused by clouds, not by data that is missing for some other reason. Any satellite product based on visible and infrared band radiances will lack information from the surface under clouds. While passive microwave based products can provide information under most types of clouds, they are currently unreliable under a number of circumstances (discussed in the next section). Considering the importance of having daily real-time information about the surface to specify boundary conditions in weather prediction models, as well to track climatological changes in snow extent, IMS, or an equivalent product that provides information for all days regardless of cloud conditions, is a necessity.

\subsection{Disagreement between AMSR-E and the other two products}

Fig. 5 includes, for each month, a map showing where AMSR-E identifies snow to the exclusion of the both MOD10C1 and IMS (Fig. 5a, c, e) and a map showing where AMSR-E finds no snow when the other two products identify snow (Fig. 5b, e, f). The most prominent feature is the red colored plateau region of central Asia seen in all maps down the left hand column (Fig. 5a, c, e). This indicates that during all months over this region AMSRE identifies snow more often than the other two products. While we do not, in general, assume that a product is wrong because it disagrees with the other two products, in this region we know from other studies that AMSR-E observations are biased due to problems in passive microwave snow detection at higher elevations associated with atmospheric influences on passive microwave retrievals (Wang and Tedesco, 2007). Since the atmosphere over the high elevation plateaus is much thinner, the algorithms calibrated globally at lower elevations require correction (Savoie et al., 2009).

Panels on the right side of Fig. 5 show that during each month there are regions where AMSR-E identifies snow less frequently than MOD10C1 or IMS (Fig. 5b, d, f). The regions shown on these panels coincide with boundary of the continental snow cover during each month (see the Rutgers University Global Snow Lab web site for climatological maps of monthly snow cover based on IMS: http://climate.rutgers.edu/snowcover/index.php). Regions near the boundary tend to have patchy, shallow snow packs. During spring (Fig. 5f) the disagreement across well defined ablation bands at the southern boundary of the continental snow pack is also likely due to significant areas of melting snow with liquid water in the snowpack.

\subsection{Disagreement between IMS and the other two products}

Fig. 6 demonstrates that the most prominent circumstance under which IMS disagrees with the other two 


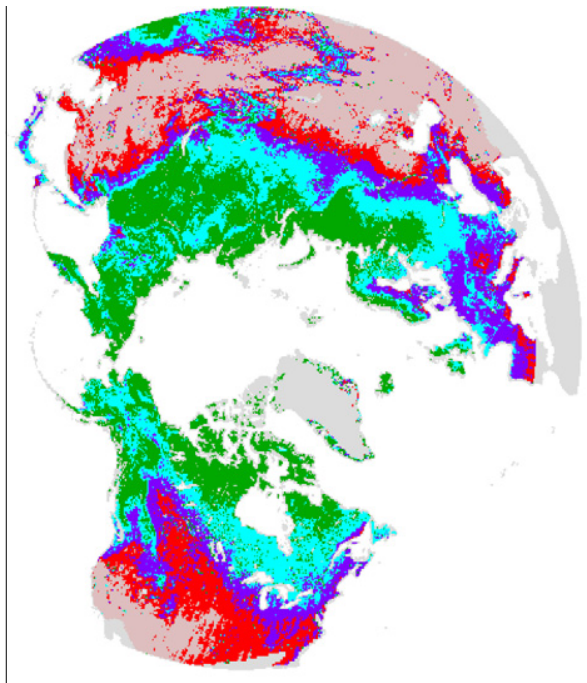

(a) October

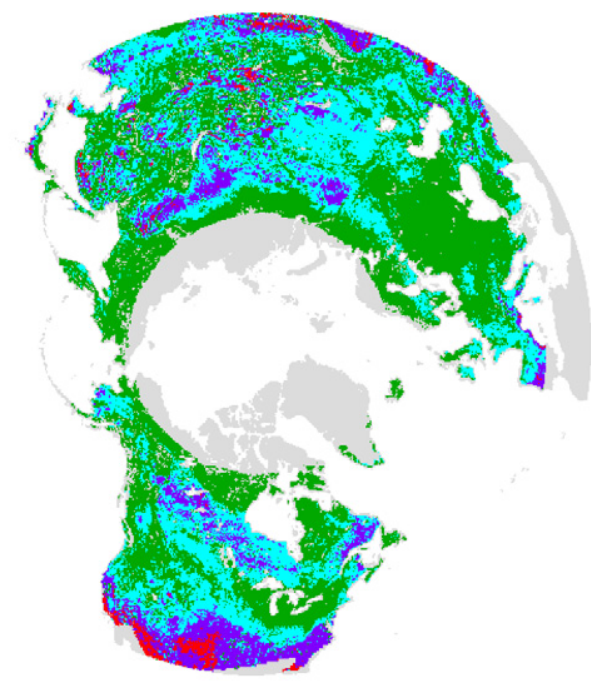

(b) January

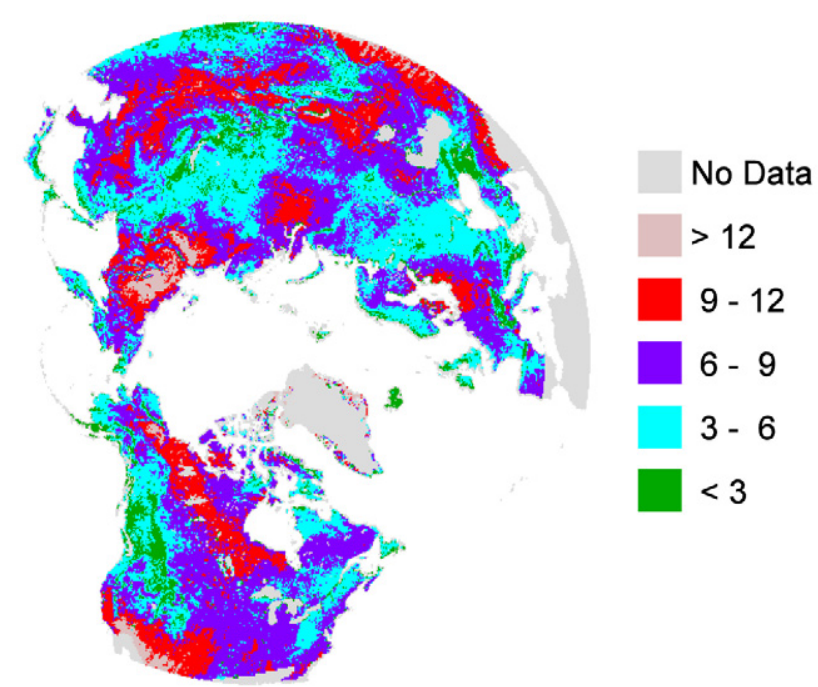

(c) April

Fig. 4. Average number of days per month at each grid point during which skies are clear and all three products are available (i.e. non-missing data) during (a) October; (b) January; (c) April.

products is during the spring ablation period near the boundary of the continental snow pack (Fig. 6e). This result is in agreement with recent studies (Brown et al., 2007, 2010; Frei and Lee, 2010) which find that over the last decade or so the timing of spring ablation over North America is later, by up to several weeks in the central Canadian Arctic, according to IMS in comparison to other observations. The reasons for these discrepancies, which are found during the entire spring ablation season (April, May, and June; May and June not shown here) over the boreal forest as well as the tundra, are not understood, but may be related to geographic factors such as the forest type and/or the presence of numerous lakes in this (Derksen et al., 2005a; Rees et al., 2006). Investigations into the cause of this problem continue.

\subsection{Disagreement between MOD10C1 and the other two products}

The most interesting example of MOD10C1 disagreeing with IMS and AMSR-E is found during autumn over Eurasia. During October over a broad, seemingly incoherent region of Eurasia, predominantly over Scandinavia and northern Europe, MOD10C1 often identifies snow when the other two products do not (Fig. 7a). However, this region is not as incoherent as it may seem, as it corresponds closely to the boreal evergreen needleleaf forest as defined by analysis of MODIS reflectance (Friedl et al., 2002). During November (not shown) we find a similar pattern, except the differences are more extreme and concentrated more over Scandinavia. The eastern Eurasian region over which 


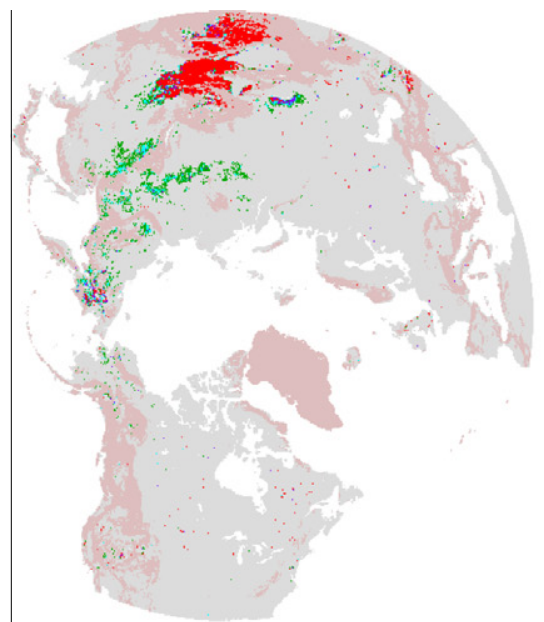

(a) October AMSR-E snow

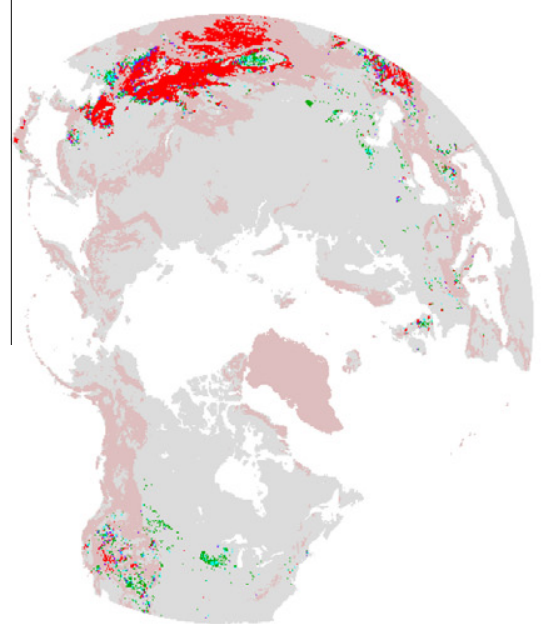

(c) January AMSR-E snow

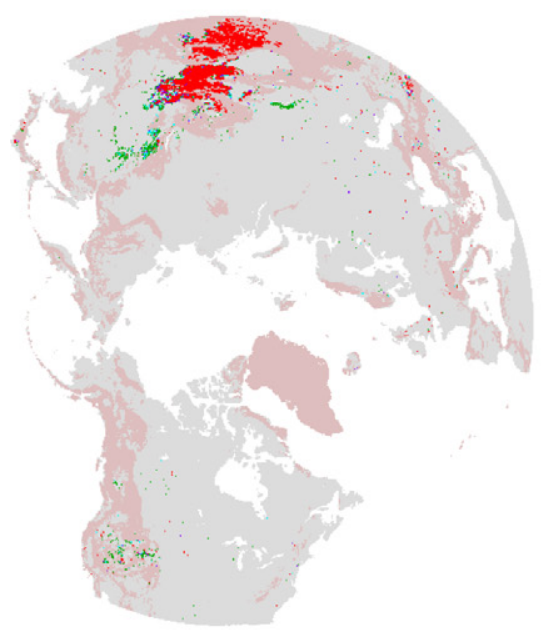

(e) April AMSR-E snow

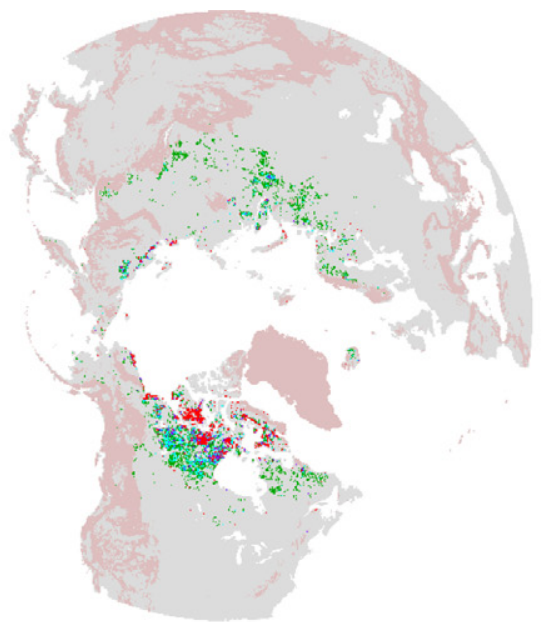

(b) October AMSR-E no-snow

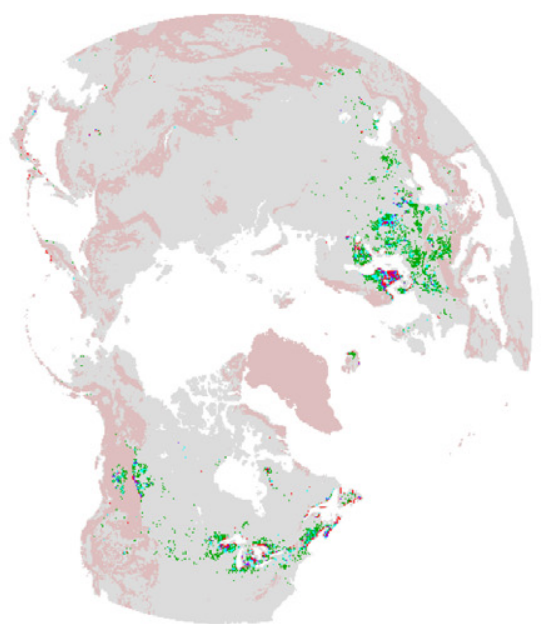

(d) January AMSR-E no-snow

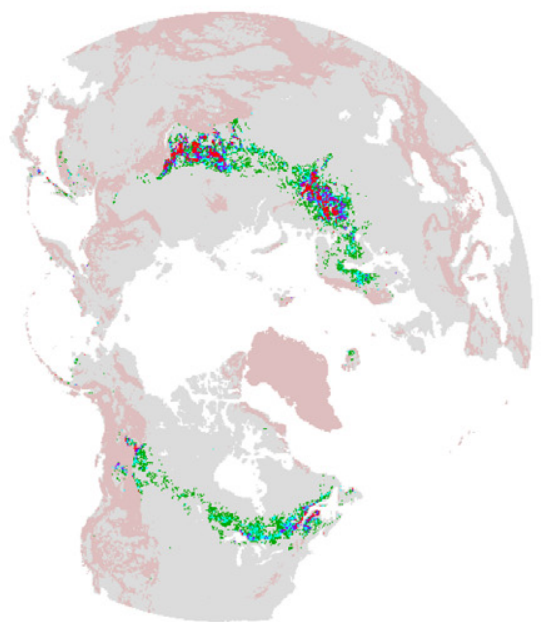

(f) April AMSR-E no-snow

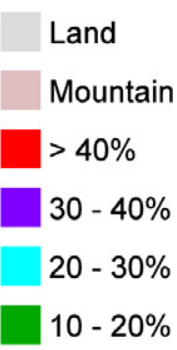

Land

Mountain

$40 \%$

$0-30 \%$

$10-20 \%$

Fig. 5. Percentage of available days during which AMSR-E disagrees with IMS and MODIS. (a) October; AMSR-E shows snow while other two products show no snow. (b) October; AMSR-E shows no snow while other two products show snow. (c) January; AMSR-E shows snow while other two products show no snow. (d) January; AMSR-E shows no snow while other two products show snow. (e) April; AMSR-E shows snow while other two products show no snow. (f) April; AMSR-E shows no snow while other two products show snow.

MOD10C1 often fails to identify snow when IMS and AMSR-E see snow (Fig. 7b) corresponds closely to the region of deciduous needleleaf forest. It seems that over one type of forest MODIS sees snow more often, while 


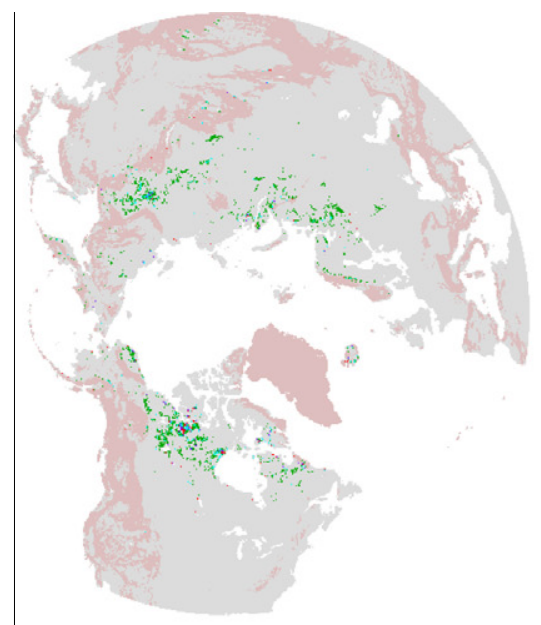

(a) October IMS snow

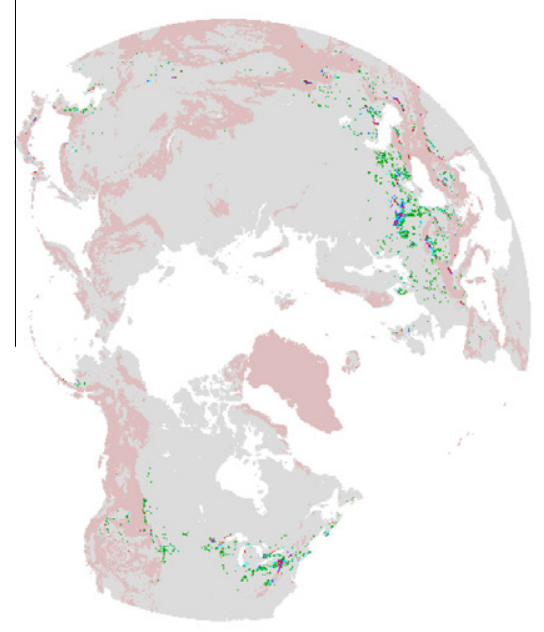

(c) January IMS snow

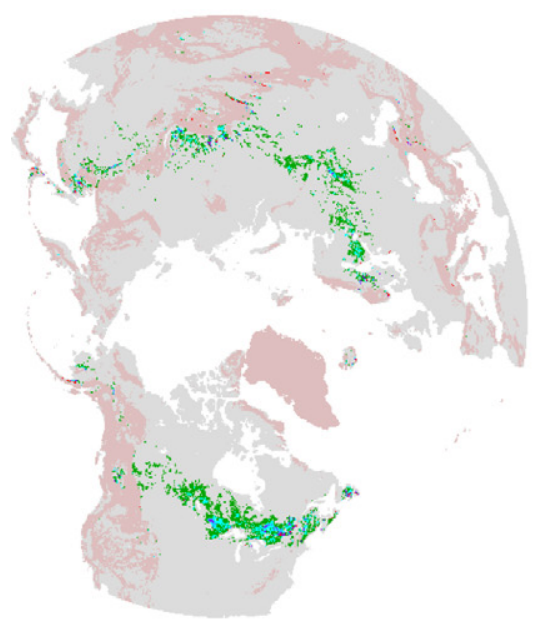

(e) April IMS snow

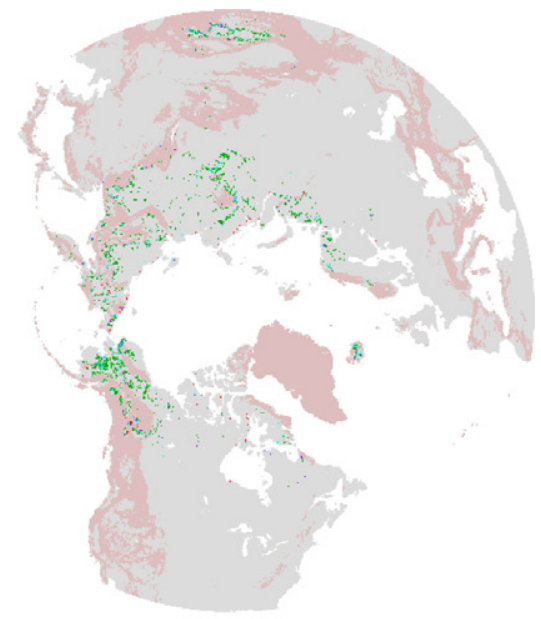

(b) October IMS no-snow

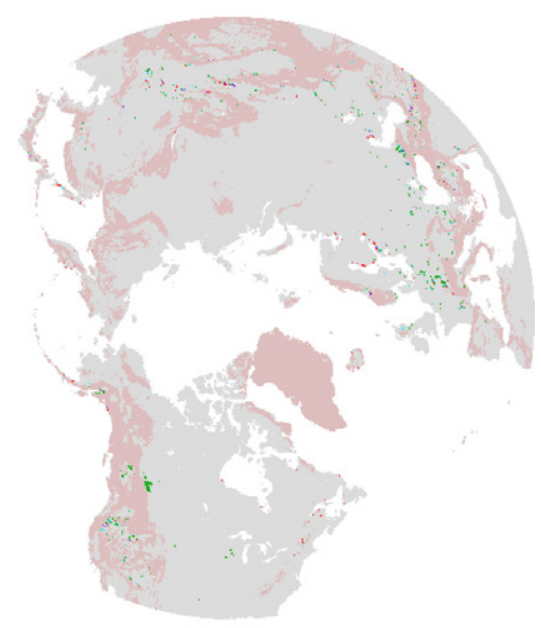

(d) January IMS no-snow

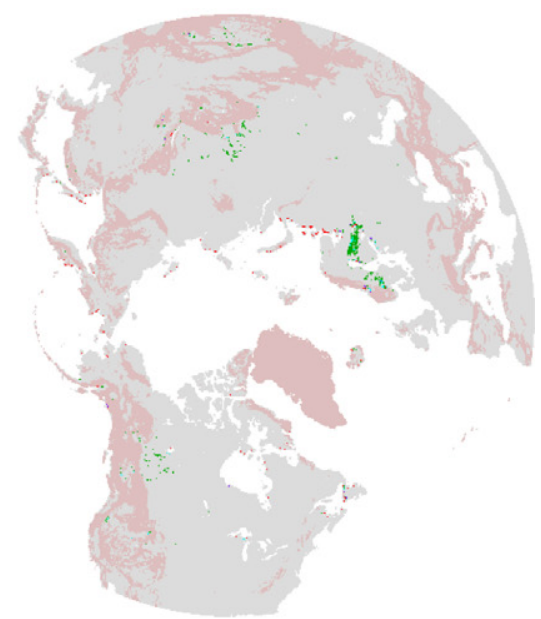

(f) April IMS no-snow

Fig. 6. Same as Fig. 5 except showing where IMS disagrees with other two products.

over a different type of forest MODIS sees snow less often. While the difficulties of remotely sensing snow under forest canopies have been widely reported, the patterns reported here have not been examined in the literature.

\subsection{Comparison of AMSR-E to the CMC snow product}

Maximum October snow depth values over the Northern Hemisphere are $\sim 20-30 \mathrm{~cm}$ (Fig. 8). The AMSR-E 


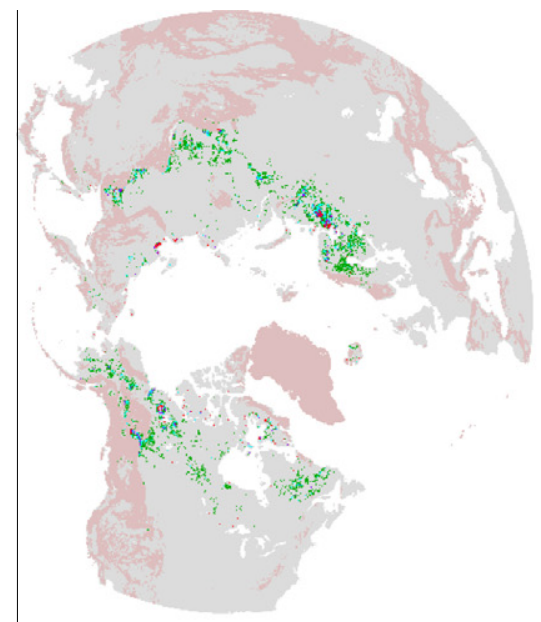

(a) October MODIS snow

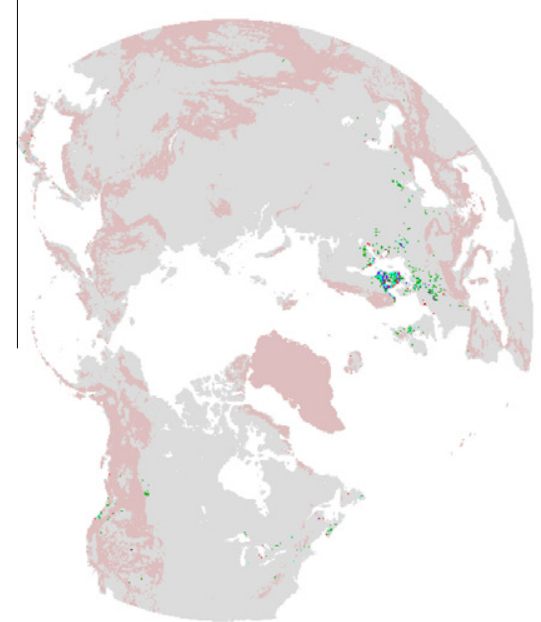

(c) January MODIS snow

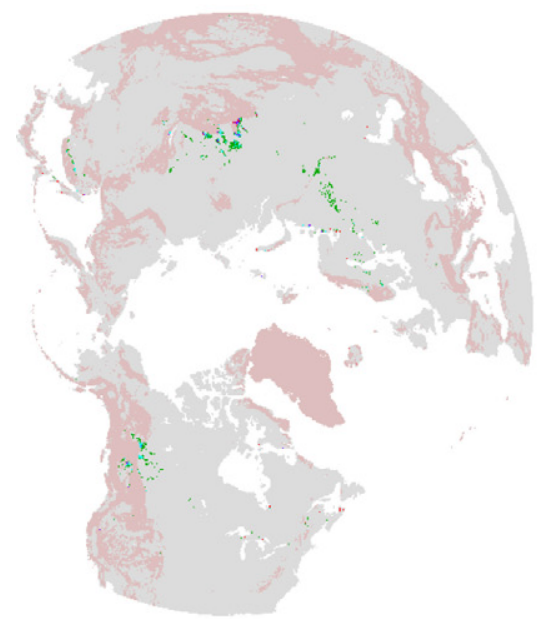

(e) April MODIS snow

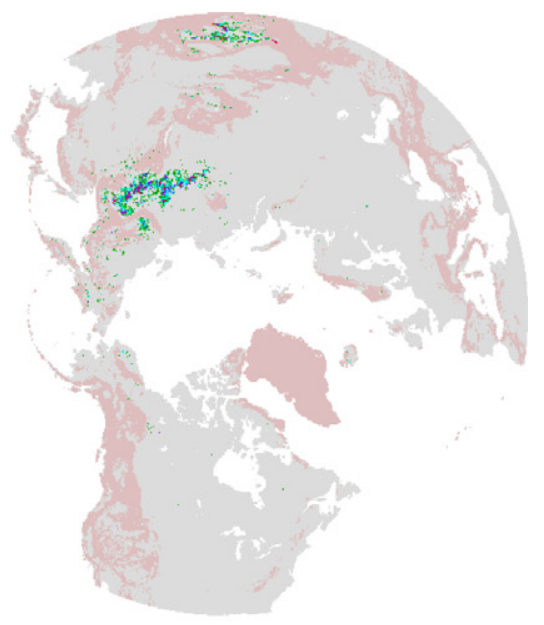

(b) October MODIS no-snow

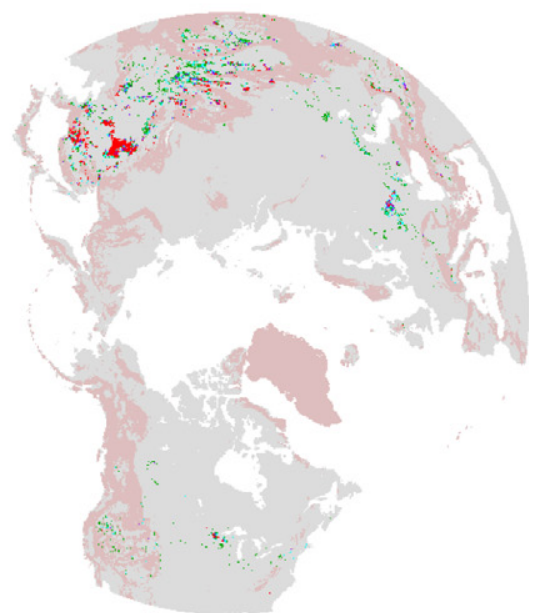

(d) January MODIS no-snow

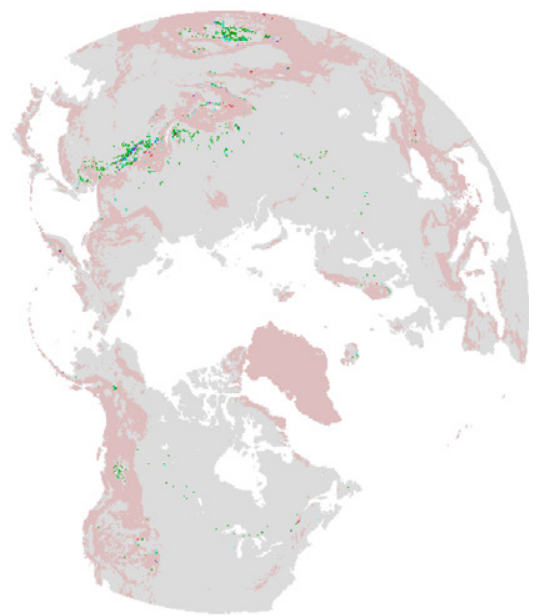

(f) April MODIS no-snow

Fig. 7. Same as Fig. 5 except showing where MODIS disagrees with other two products.

product suggests more snow in Siberia than the CMC product. AMSR-E overestimation with respect to CMC over Siberia increases as the snow season progresses. In January, snow depth differences between the two products increase to $\sim 30-40 \mathrm{~cm}$ (Fig. 9). In April, the area over which AMSR-E overestimates snow depth increases even further with respect to January. In contrast, over other regions AMSR-E tends to underestimate snow depth with 


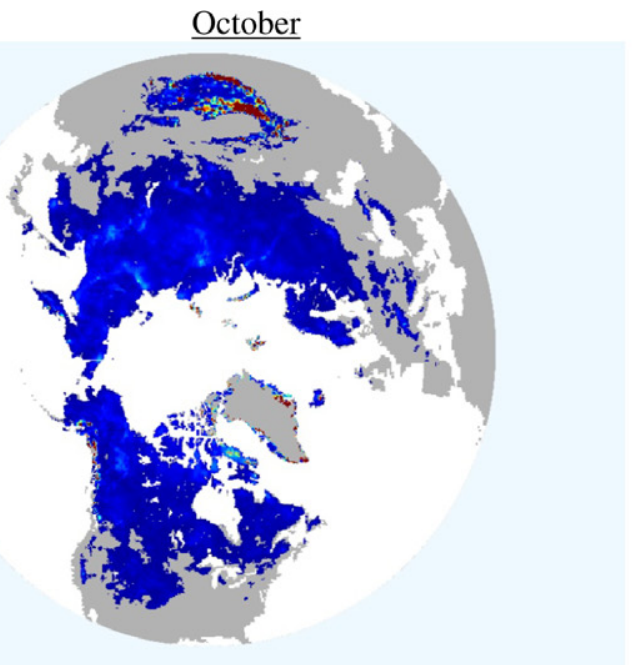

(a)

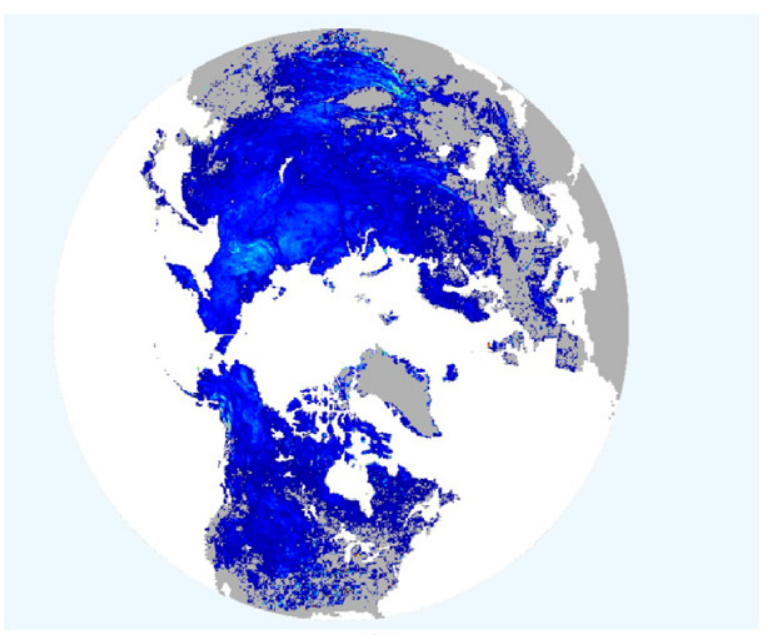

(b)

\begin{tabular}{lllcccccc}
\hline 0 & 10 & 20 & 30 & $\begin{array}{c}1 \\
40 \\
{[\mathrm{~cm}]}\end{array}$ & 50 & 60 & 70 & 80 \\
\hline
\end{tabular}

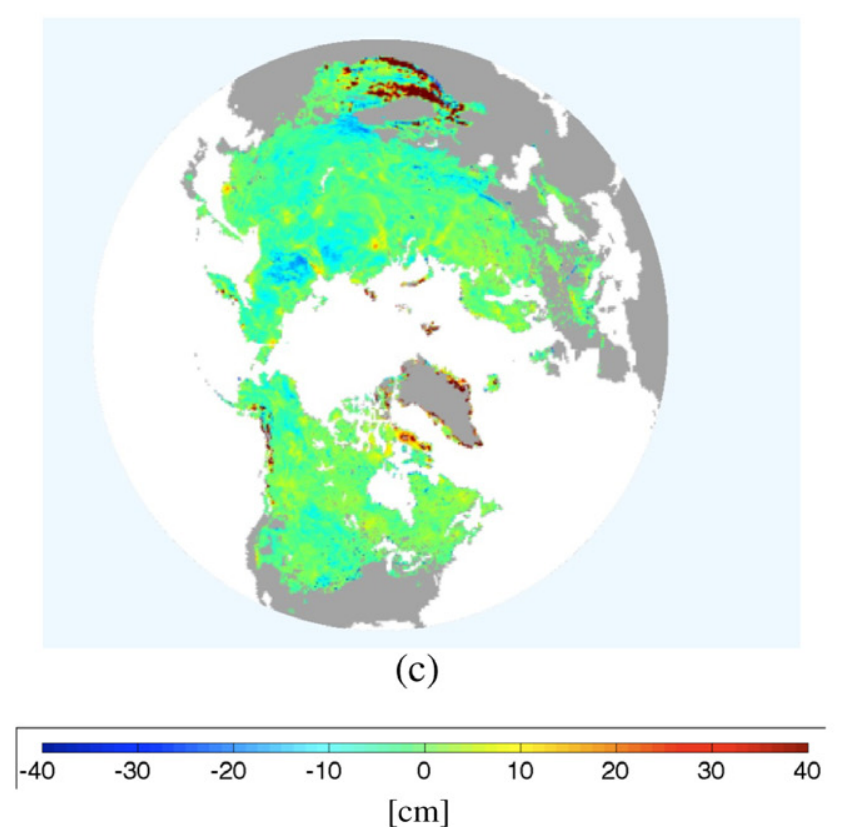

Fig. 8. Comparison of ASMR-E and CMC snow depth for October. (a) CMC estimated monthly mean snow depth. (b) AMSR-E estimated monthly mean snow depth. (c) Difference (CMC - AMSR-E) in monthly mean snow depths.

respect to the $\mathrm{CMC}$ product, but these areas do not appear to expand as the snow season progresses. These include the Tibetan plateau and along the north-east coast of North America (Fig. 10).

Histograms of the snow depth differences between the two products are shown in Fig. 11. Overall, AMSR-E tends to overestimate the values provided by CMC. While the variance of the errors can be seen in the histogram plots, perhaps a more informative number would be the coefficient of variation $(C v)$. $C v$ defined as the absolute value of the standard deviation of the differences divided by the mean CMC snow depth, provides an indication of how large the differences are in comparison to the snow depth. For example, a value of $C v=1$ means that the errors are of the same magnitude as the mean depth; $C v=0.1$ means that the errors or an order of magnitude less than the mean snow depth. $C v$ values were calculated for each month (Table 1). $C v$ values are highest in October, when depths are small; lowest in January; and increase again in April. As a snow pack ages, even under cold conditions without additional precipitation, metamorphic processes lead to grain size variations (such as depth hoar formation) that tend to introduce errors in the passive microwave product. Furthermore, as temperatures fluctuate and additional 


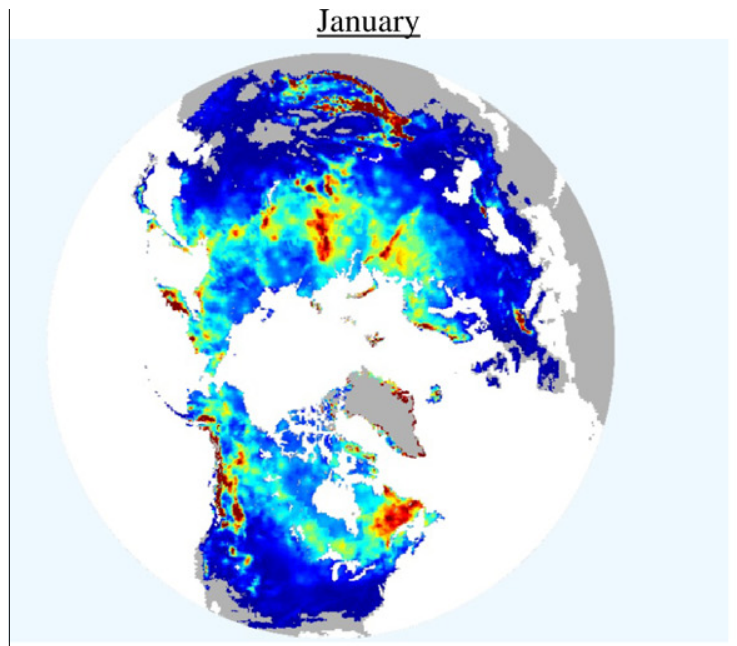

(a)

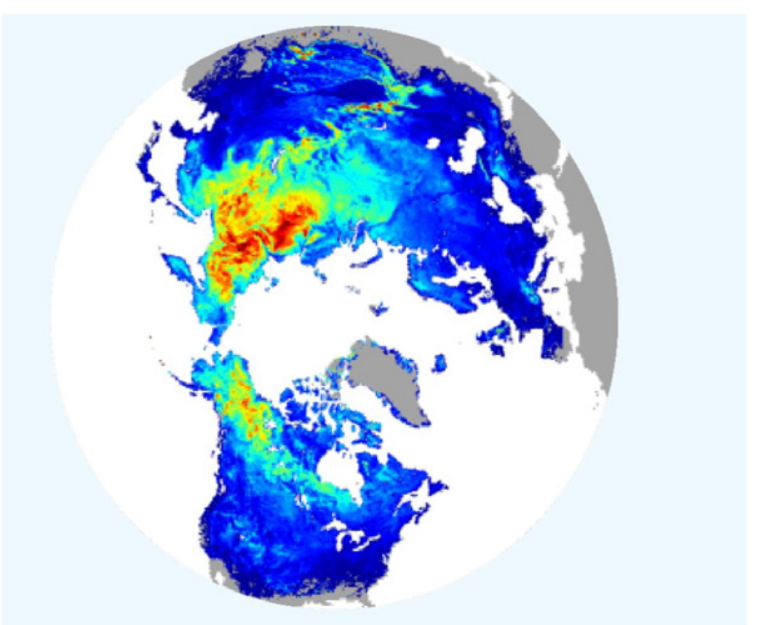

(b)
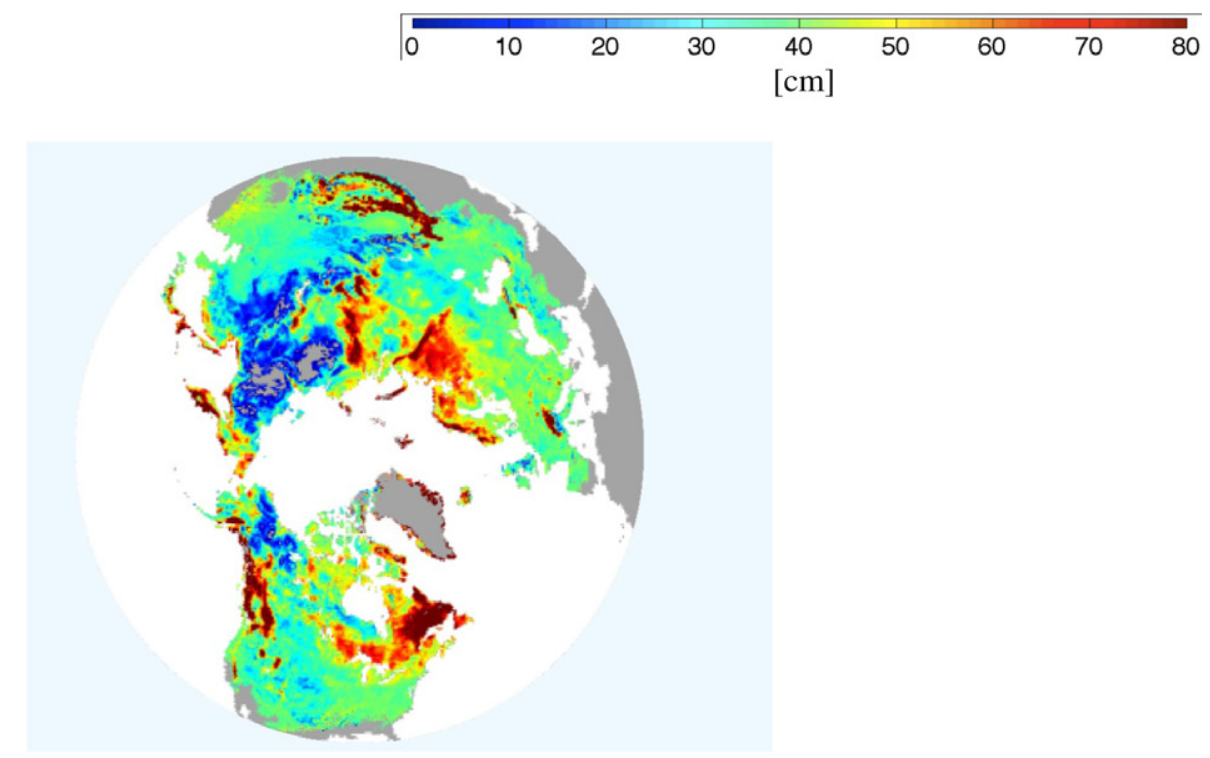

(c)

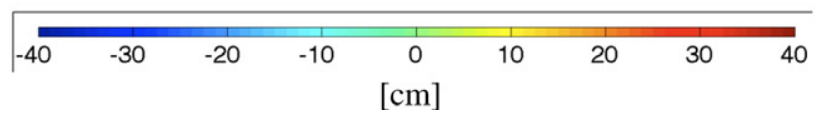

Fig. 9. Same as Fig. 8 but for January.

precipitation events add fresh snow, snow packs can develop a series of well defined layers of different grain sizes that confound passive microwave based estimates of depth and SWE. Ice layers, which can develop as a result of melt-freeze and rain-freeze events, introduce additional scattering and therefore additional uncertainty. Such complications, combined with the impact of vegetation, especially vegetation that can change seasonally, can introduce a growing error in passive microwave retrievals as the snow season progresses.

Improved confidence in our abilities to estimate snow mass from satellites would support efforts to monitor the fresh water flux into the Arctic Ocean. An order of magnitude estimate suggests that the volume of water in the snow pack can play a significant role in the total annual river runoff into the Arctic Ocean of $4300-4800 \mathrm{~km}^{3} \mathrm{yr}^{-1}$ (Arnell, 2005; Miller and Russell, 2000). Our AMSR-E based (highly uncertain) estimate of the mean snow mass over land surfaces during March (the month of maximum snow mass) north of $60 \mathrm{~N}$ is $\sim 1600 \mathrm{~km}^{3}$. Frei et al. (2005) based on the analysis of Brown et al. (2003) estimated the observed mean snow volume over North America during March to be $\sim 1500 \mathrm{~km}^{3}$, which was equal to the median value estimated by a group of 18 climate models. This compares to a recent passive microwave-based estimate of $\sim 1400 \mathrm{~km}^{3}$ and $\sim 2300 \mathrm{~km}^{3}$ for mean North American and Eurasian snow volumes, respectively (Biancamaria et al., 2011). The errors associated with most of these 


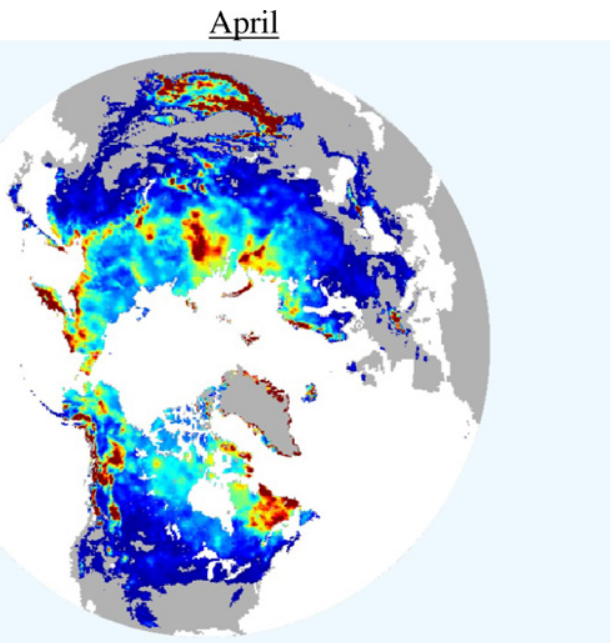

(a)

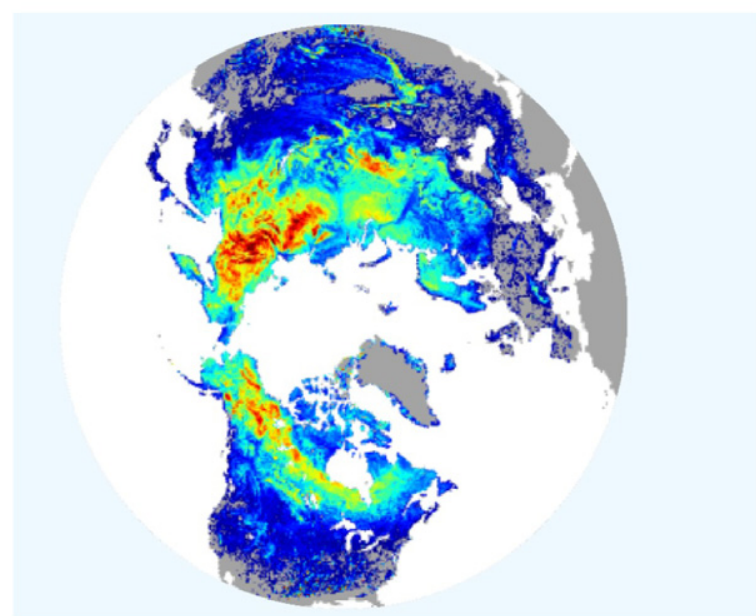

(b)

\begin{tabular}{llllcllll}
\hline 0 & 10 & 20 & 30 & $\begin{array}{c}10 \\
{[\mathrm{~cm}]}\end{array}$ & 50 & 60 & 70 & 80 \\
\hline
\end{tabular}

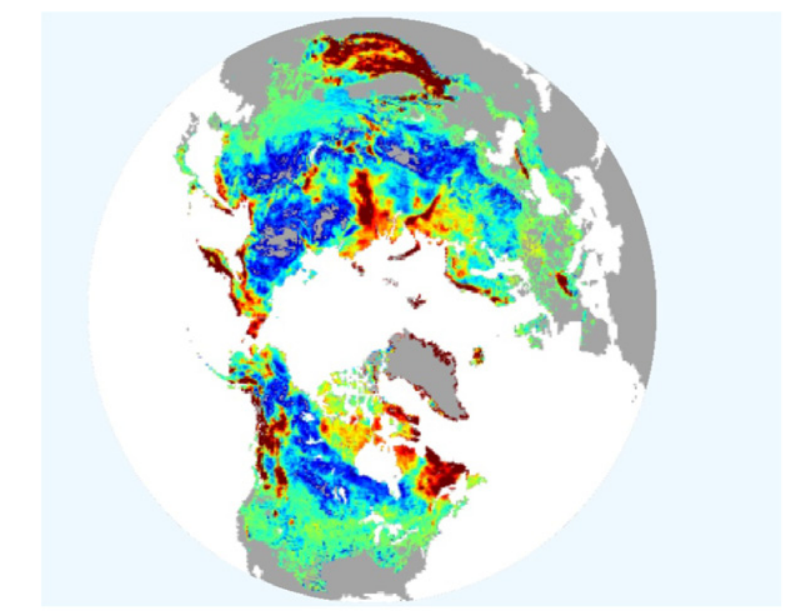

(c)

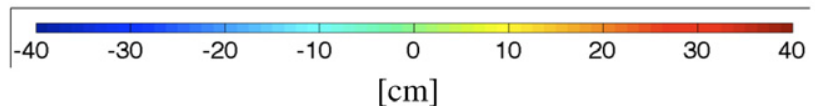

Fig. 10. Same as Fig. 8 but for April.

estimates are currently unknown, but they indicate that the snowpack provides a significant fraction of the total river runoff to the Arctic.

\section{Discussion and conclusions}

For most of the snow season and most regions there is large-scale agreement amongst the products in identifying the location of snow covered surfaces (i.e. snow extent, regardless of snow depth) during clear sky conditions. One exception to this is over central Asia. It is known that passive microwave products identify snow on the Tibetan Plateau and surrounding mountains when visible and infrared products do not (Armstrong and Brodzik, 2001; Basist et al., 1996). Because passive microwave retrieval algorithms are calibrated at lower elevations, at these high elevations the reduced atmosphere between the surface and radiometer can result in retrieval errors (Savoie et al., 2009; Wang and Tedesco, 2007). The second exception occurs where snow is ephemeral, patchy, or wet. In such regions the attenuation of the passive microwave signal, upon which snow detection is based, is compensated for by emission from the surface or from liquid water in the snow pack (Matzler, 1994; Ulaby and Stiles, 1980). Despite these difficulties, all estimates (discussed in the preceding section) indicate that the snowpack is the source of a significant portion of runoff into the Arctic basin.

The disagreements in snow extent during April are greater than during October or January in terms of the percentage of available days during which one product differs 


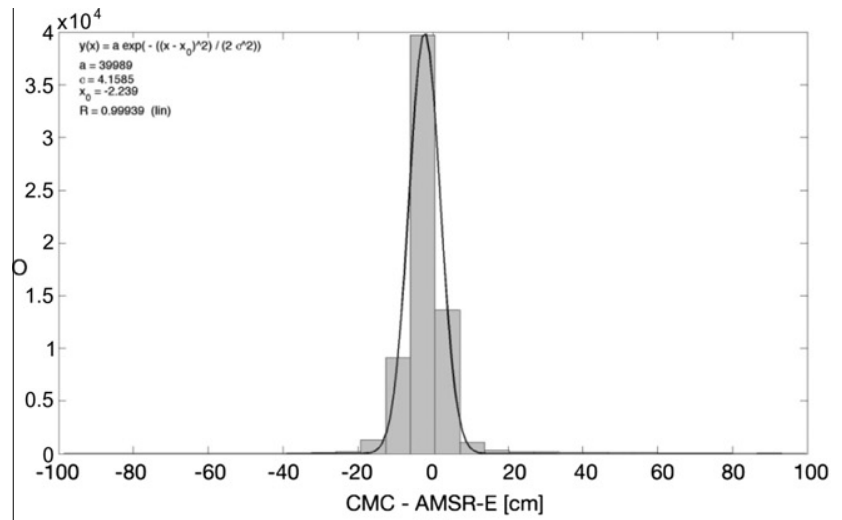

(a)

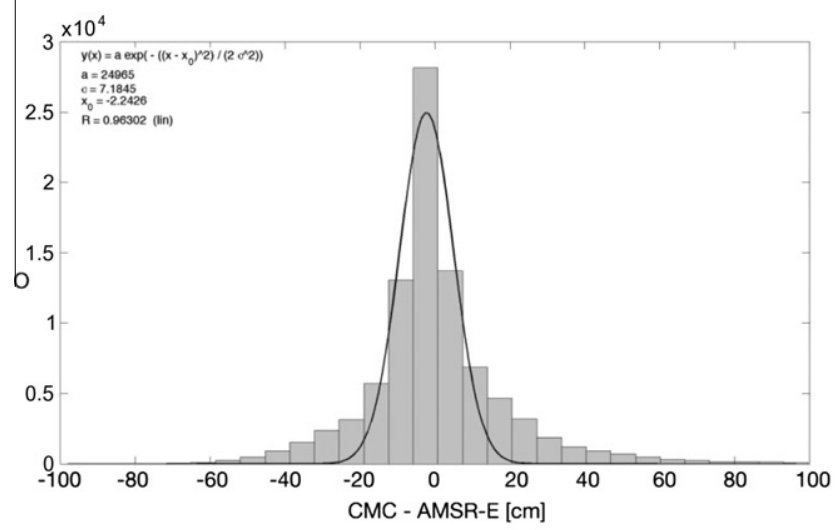

(b)

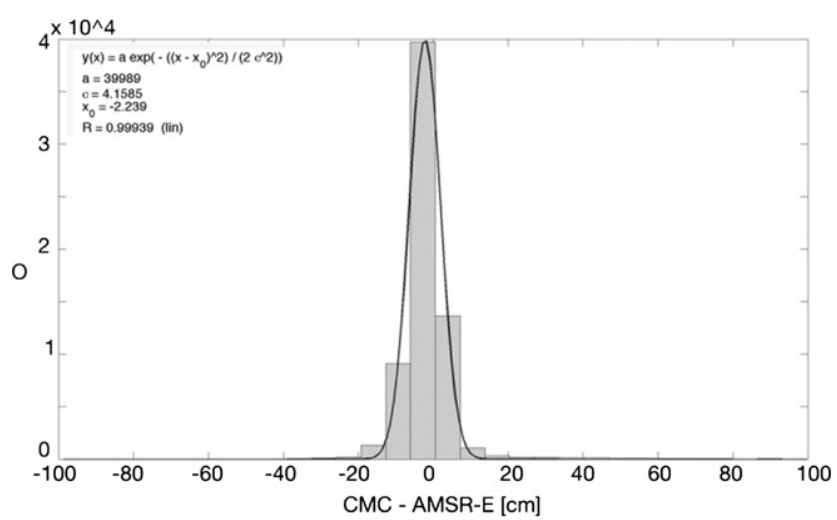

(c)

Fig. 11. Histograms of differences in snow depth (CMC - AMSR-E) for all grid points for (a) October, (b) January, and (c) April.

from the other two. This is in agreement with Brown et al. (2010), Frei and Lee (2010), and Brown et al. (2007), who find differences between sensors during spring over North American regions experiencing ablation, and indicates that the wet snow during ablation is perhaps more of a hindrance to the identification of snow from satellites than some of the other confounding factors. However, during fall and winter the evaluation is hampered by data availability problems associated with cloudiness and solar illumination issues.

Our analysis also demonstrates that snow depths estimated by the Canadian Meteorological Centre product
Table 1

Mean snow depth from CMC product; standard deviation of the differences between the CMC and AMSR-E snow depths; and the coefficient of variation. All values are averages of grid points across all Northern Hemisphere land areas north of $30 \mathrm{~N}$ excluding the Greenland ice sheet.

\begin{tabular}{llll}
\hline & $\begin{array}{l}\mu \text { (mean CMC } \\
\text { snow depth) } \\
(\mathrm{cm})\end{array}$ & $\begin{array}{l}\sigma \text { (standard } \\
\text { deviation of } \\
\text { difference) }(\mathrm{cm})\end{array}$ & $\begin{array}{l}C v \text { abs }(\sigma \mu) \text { (coefficient } \\
\text { of variation) (unitless) }\end{array}$ \\
\hline October & 5.0 & 4.15 & 0.83 \\
January & 22.5 & 7.18 & 0.32 \\
April & 22.9 & 12.33 & 0.54 \\
\hline
\end{tabular}

and by the AMSR-E algorithm can differ substantially. Although there are no absolute surface reference observations in most regions to determine which (if either) product is correct, we know from experience as well as theory that the passive microwave depth and SWE algorithms are inaccurate under certain conditions (Tedesco and Narvekar, 2010). Sources of error include: surface heterogeneity within a passive microwave footprint; temporal and spatial variability in grain size and snow density; obscuration of snow by forests; masking of the passive microwave signal by liquid water in the snow pack; and effects of atmospheric attenuation. The persistent underestimation by AMSR-E with respect to CMC over some regions can be partially explained by considering that snow depth over many of those areas is above the 'saturation' depth to which the passive microwave algorithm is sensitive (Derksen, 2008; Markus et al., 2006; Matzler, 1994; Schanda et al., 1983); the presence of a high fraction of lakes over the north east of North America is also believed to be a source of error (Derksen et al., 2005a; Rees et al., 2006).

Another example is the overestimation of snow depth by AMSR-E over northern Siberia, which can be attributed to the limitation of the current AMSR-E algorithm to account for the large grains that typically develop in snow packs in this (and some other) regions (Clifford, 2010). Over regions that develop and maintain a snow pack early in the season, the snow tends to insulate the ground keeping it warm even as air temperatures fall, resulting in a strong vertical temperature gradient in the snow pack. This temperature gradient causes vertical energy and vapor fluxes within the snow pack, the net effect of which is a layer of depth hoar at the bottom of the snow pack (Jordan et al., 2008). The large crystal sizes of depth hoar $(\sim 5 \mathrm{~mm})$ cause increased scattering of microwave radiation resulting in an overestimation of the snow pack by the passive microwave algorithms.

Opportunities remain for the development of improved snow products. For example, improvements can be made with regard to the retrieval of snow amount from passive microwave sensors (Tedesco et al., 2004) under forested terrain (Derksen, 2008), the refinement of snow extent estimates from visible and infrared sensors (Parajka et al., 2008), and the estimation of sub-grid scale information. Tedesco and Miller (2007b) explore the relative merits of 
combining active and passive microwave retrievals, using a MODIS snow product as their reference "truth." A number of researchers are investigating the potential for finer scale information on snow extent, amount, fractional snow cover (Derksen et al., 2005b; Salomonson and Appel, 2004, 2006), snow melt (Wang et al., 2008), as well as on snow pack properties (Kinar and Pomeroy, 2007; Nolin and Dozier, 2000; Painter and Dozier, 2004; Painter et al., 2003; Rango et al., 2000; Schmugge et al., 2002). Improvements in remotely sensed products that do not rely on the assimilation of data or model results will come as a consequence of improved understanding of the interaction between electromagnetic and geophysical parameters at large spatial scales. In this context, a new operational algorithm based on the inversion of an electromagnetic model, artificial neural networks and snow climatology currently under evaluation may be capable of accounting for some of these limitations.

One currently active area of research is the development of combined products, which include in situ observations and/or modeling results as well as remotely sensed information. One can identify advantages and disadvantages to both combined and stand-alone remotely sensed products. While stand-alone remotely sensed products contain inherent drawbacks as discussed here, at any time, either in situ or remotely sensed data streams can fail, rendering combined as well as stand-alone products vulnerable to missing information. This is most critical for real- or near-real time operational products, on which weather forecast models or time-sensitive decisions rely.

Remote sensing of snow continues to contribute to our understanding of Earth system processes. MODIS snow products are valuable because they can provide high resolution snow estimates under cloud-free conditions using a quantifiable algorithm. However, for climatological as well as operational purposes, humans can integrate and filter data from multiple sources and satellite images in ways that fully automated methods are (at least currently) unable to, and provide information for the entire land surface of the globe, regardless of the presence of clouds. Thus, continuation of IMS, with its long record of snow extent, is a priority. Considering the difficulties in determining SWE on a global scale from stand-alone remote sensing products, it seems likely that combining multiple sensors with station observations and/or models, such as in the GlobSnow product will provide the best estimates of SWE.

\section{Acknowledgements}

Frei is supported by the NASA Cryospheric Sciences Program award \#NNX08AQ70G, and began work on this article while on sabbatical leave at the Climate Research Division of Environment Canada in Downsview, Ontario. M. Tedesco is supported by NASA Grant \# NNX08AI02G. D. Robinson acknowledges funding support from NASA MEaSUREs award NNX08AP34A and NOAA Climate
Program Office awards EA133E10SE2623 and NA08AR 4310678. Two anonymous reviewers made valuable contributions to, and helped clarify, our manuscript; and we thank $\mathrm{T}$. Estilow and Jeff Miller for contributions to the figures.

\section{References}

ACIA Impacts of a Warming Arctic: Arctic Climate Impact Assessment, ACIA. Cambridge University Press, 140 p. Available from: $<$ http:// www.amap.no/; http://amap.no/acia/>., 2004.

AMAP. SWIPA (Snow, Water, Ice, and Permafrost in the Arctic) Executive Summary. Oslo, Norway, Arctic Monitoring and Assessment Program: 15 p., 2011.

Armstrong, R.L., Brodzik, M.J. Recent Northern Hemisphere snow extent: a comparison of data derived from visible and microwave satellite sensors. Geophysical Research Letters 28 (19), 3673-3676, 2001.

Arnell, N.W. Implications of climate change for freshwater inflows to the Arctic Ocean. Journal of Geophysical Research 110, D07105, 2005.

Barnett, T.P., Adam, J.C., Lettenmaier, D.P. Potential impacts of a warming climate on water availability in snow-dominated regions. Nature 438, 303-309, 2005.

Barry, R. The role of snow and ice in the global climate system: a review. Polar Geography 26 (3), 235-246, 2002.

Barry, R.G., Fallot, J.-M., Armstrong, R.L. Twentieth-century variability in snow-cover conditions and approaches to detecting and monitoring changes: status and prospects. Progress in Physical Geography 19 (4), 520-532, 1995 .

Barry, R.G., Armstrong, R., Callaghan, T., Cherry, J., Gearhead, S., Nolin, A., Russell, D., Zockler, C. Snow. Global Outlook for Ice and Snow. UNEP. Nairobi, Kenya, United Nations Environment Program: pp. 39-62, 2007.

Basist, A., Garrett, D., Ferraro, R., Grody, N., Mitchell, K. A comparison between snow cover products derived from visible and microwave satellite observations. Journal of Applied Meteorology 35, 163-177, 1996.

Betts, R.A. Offset of the potential carbon sink from boreal forestation by decreases in surface albedo. Nature 408 (6809), 187-190, 2000.

Biancamaria, S., Cazevave, A., Mognard, N.M., Llovel, W., Frappart, F. Satellite-based high latitude snow volume trend, variability and contribution to sea level over 1989/2006. Global and Planetary Change 75, 99-107, 2011

Bitner, D., Carroll, T., Cline, D., Romanov, P. An assessment of the differences between three satellite snow cover mapping techniques. Hydrological Processes 16, 3723-3733, 2002.

Brasnett, B. A global analysis of snow depth for numerical weather prediction. Journal of Applied Meteorology 38 (6), 726, 1999.

Brodzik, M.J., Knowles, K. EASE-Grid: A Versatile Set of Equal-area Projections and Grids, in: M. Goodchild (Ed.), Discrete Global Grids. National Center for Geographic Information Analysis, Santa Barbara, California, USA, 2002.

Brodzik, M.J., Armstrong, R.A., Savoie, M. Global EASE-Grid 8-day Blended SSM/I and MODIS Snow Cover, 2007. Available from: $<$ http://nsidc.org/data/docs/daac/nsidc0321_8day_ssmi_modis_blend/ index.html $>$.

Brown, R., Armstrong, R.L. Snow-cover data: measurement, products, sources, in: Armstrong, R.L., Brun, E. (Eds.), Snow and Climate: Physical Processes, Surface Energy Exchange and Modeling. Cambridge University Press, pp. 181-216, 2008.

Brown, R., Derksen, C., Wang, L. Assessment of spring snow cover duration variability over northern Canada from satellite datasets. Remote Sensing of Environment 111, 367-381, 2007.

Brown, R., Derksen, C., Wang, L. A multi-data set analysis of variability and change in Arctic spring snow cover extent, 1967-2008. Geophysical Research Letters 115 (D16111), 16, 2010.

Brown, R.D. Northern Hemisphere snow cover variability and change, 1915-1997. Journal of Climate 13 (13), 2339-2355, 2000. 
Brown, R.D., Braaten, R.O. Spatial and temporal variability of Canadian monthly snow depths, 1946-1995. Atmosphere-Ocean 36, 37-45, 1998.

Brown, R.D., Mote, P.W. The response of Northern Hemisphere snow cover to a changing climate. Journal of Climate 22, 2124-2145, 2009.

Brown, R.D., Brasnett, B., Robinson, D.A. Gridded North American monthly snow depth and snow water equivalent for GCM evaluation. Atmosphere-Ocean 41 (1), 1-14, 2003.

Brubaker, K.L., Pinker, R.T., Deviatova, E. Evaluation and comparison of MODIS and IMS snow-cover estimates for the continental United States using station data. Journal of Hydrometeorology 6, 1002-1017, 2005.

Carroll, T. Operational airborne measurements of snow water equivalent and soil moisture using terrestrial gamma radiation in the United States, in: Goodison, B., Barry, R.G., Dozier, J. (Eds.), Large Scale Effects of Seasonal Snow Cover (Proceedings of the Vancouver Symposium, August 1987). Vancouver, BC, IAHS, pp. 213-223, 1987.

Carroll, T., Cline, D., Fall, G., Nilsson, A., Li, L., Rost, A. NOHRSC operations and the simulation of snow cover properties for the coterminous US, in: 69th Annual Meeting of the Western Snow Conference, Sun Valley, Idaho, pp. 2-14, 2001.

Chang, A.T.C., Foster, D.R., Hall, D.K. Nimbus-7 SMMR derived global snow cover parameters. Annals of Glaciology 9, 39-44, 1987.

Chang, A.T.C., Foster, D.R., Hall, D.K. Effects of forest on the snow parameters derived from microwave measurements during the BOREAS winter field campaign. Hydrological Processes 10, 15651574, 1996

Chang, A.T.C., Gloersen, P., Schmugge, T.J., Wilheit, T., Zwally, H.J. Microwave emission from snow and glacier ice. Journal of Glaciology 16 (74), 23-39, 1976.

Chang, A.T.C., Kelly, R.E.J., Josberger, E.G., Armstrong, R.L., Foster, J.L., Mognard, N.M. Analysis of ground-measured and passivemicrowave-derived snow depth variations in midwinter across the northern Great Plains. Journal of Hydrometeorology 6, 20-33, 2005.

Clifford, D. Global estimates of snow water equivalent from passive microwave instruments: history, challenges and future developments. International Journal of Remote Sensing 31 (14), 3707-3726, 2010.

Cohen, J. Snow cover and climate. Weather 49 (5), 150-156, 1994.

Derksen, C. The contribution of AMSR-E 18.7 and $10.7 \mathrm{GHz}$ measurements to improved boreal forest snow water equivalent retrievals. Remote Sensing of Environment 112, 2701-2710, 2008.

Derksen, C., Walker, A.E. Identification of systematic bias in the crossplatform (SMMR and SMM/I) EASE-Grid brightness temperature time series. IEEE Transactions on Geoscience and Remote Sensing 41 (4), 910-915, 2003.

Derksen, C., Walker, A.E., Goodison, B.E. A comparison of 18 winter seasons of in situ and passive microwave-derived snow water equivalent estimates in Western Canada. Remote Sensing of Environment 88, 271-282, 2003.

Derksen, C., Brown, R., Walker, A.E. Merging conventional (1915-92) and passive microwave (1978-2002) estimates of snow extent and water equivalent over central North America. Journal of Hydrometeorology 5, 850-861, 2004.

Derksen, C., Walker, A., Goodison, B. Evaluation of passive microwave snow water equivalent retrievals across the boreal forest/tundra transition of western Canada. Remote Sensing of Environment 96, 315-327, 2005a.

Derksen, C., Walker, A.E., Goodison, B.E., Strapp, J.W. Integrating in situ and multiscale passive microwave data for estimation of subgrid scale snow water equivalent distribution and variability. IEEE Transactions on Geoscience and Remote Sensing 43 (5), 960-972, 2005b.

Derksen, C., Toose, P., Rees, A., Wang, L., English, M., Walker, A., Sturm, M. Development of a tundra-specific snow water equivalent retrieval algorithm for satellite passive microwave data. Remote Sensing of Environment 114, 1699-1709, 2010.

Dozier, J. Spectral signature of alpine snow cover from the landsat thematic mapper. Remote Sensing of Environment 28, 9-22, 1989.
Drusch, M., Vasiljevic, D., Viterbo, P. ECMWF's global snow analysis: assessment and revision based on satellite observations. Journal of Applied Meteorology 43, 1282-1294, 2004.

Dyer, J.L. Snow depth and streamflow relationships in large north american watersheds. Journal of Geophysical Research 113, D18113, 2008.

Dyer, J.L., Mote, T.L. Spatial variability and trends in snow depth over North America. Geophysical Research Letters 33, L16503, 2006.

Ellis, A.W., Leathers, D.J. Analysis of cold airmass temperature modification across the US great plains as a consequence of snow depth and albedo. Journal of Applied Meteorology 38 (6), 696-711, 1999.

Foster, J., Liston, G., Koster, R., Essery, R., Behr, H., Dumenil, L., Verseghy, D., Thompson, S., Pollard, D., Cohen, J. Snow cover and snow mass intercomparison of general circulation models and remotely sensed datasets. Journal of Climate 9, 409-426, 1996.

Foster, J.L., Chang, A.T.C., Hall, D.K. Comparison of snow mass estimates from a prototype passive microwave snow algorithm, a revised algorithm and a snow depth climatology. Remote Sensing of Environment 62, 132-142, 1997.

Foster, J.L., Hall, D.K., Kelly, R.E.J., Chiu, L. Seasonal snow extent and snow mass in South America using SMMR and SSM/I passive microwave data (1979-2006). Remote Sensing of Environment 113, 291-305, 2008.

Foster, J.L., Hall, D.K., Eylander, J.B., Riggs, G.A., Nghiem, S.V., Tedesco, M., Kim, E., Montesano, P.M., Kelly, R.E.J., Casey, K.A., Choudhury, B. A blended global snow product using visible, passive microwave and scatterometer data. International Journal of Remote Sensing 32 (5-6), 1371-1395, 2011.

Francis, J.A., White, D., Cassano, J., Gutkowski, W.J., Hinzman, L.D., Holland, M., Steele, M., Vorosmarty, C.J. An Arctic hydrologic system in transition: feedbacks and impacts on terrestrial, marine, and human life. Journal of Geophysical Research 115, G04019, 2009.

Frei, A., Gong, G. Decadal to century scale trends in North American snow extent in coupled atmosphere-ocean general circulation models. Geophysical Research Letters 32 (18), L18502, 5 pp., 2005.

Frei, A., Lee, S. A comparison of optical-band based snow extent products during spring over North America. Remote Sensing of Environment 114, 1940-1948, 2010.

Frei, A., Robinson, D.A., Hughes, M.G. North American snow extent: 1900-1994. International Journal of Climatology 19, 1517-1534, 1999.

Frei, A., Miller, J.A., Robinson, D.A. Improved simulations of snow extent in the second phase of the Atmospheric Model Intercomparison Project (AMIP-2). Journal of Geophysical Research - Atmospheres 108 (D12), 4369, doi:10.1029/2002JD003030, 2003.

Frei, A., Brown, R., Miller, J.A., Robinson, D.A. Snow mass over North America: observations and results from the second phase of the Atmospheric Model Intercomparison Project (AMIP-2). Journal of Hydrometeorology 6 (5), 681-695, 2005.

Friedl, M.A., McIver, D.K., Hodges, J.C.F., Zhang, X.Y., Muchoney, D., Strahler, A.H., Woodcock, C.E., Gopal, S., Schneider, A., Cooper, A., Baccini, A., Gao, F., Schaaf, C. Global land cover mapping from MODIS: algorithms and early results. Remote Sensing of Environment 83 (1-2), 287-302, 2002.

Ge, Y., Gong, G. Observed Inconsistencies between snow extent and snow depth variability at regional/continental scales. Journal of Climate 21 , 1066-1082, 2008.

Goita, K., Walker, A., Goodison, B. Algorithm development for the estimation of snow water equivalent in the boreal forest using passive microwave data. International Journal of Remote Sensing 24, 1097 1102, 2003.

Goodison, B., Ferguson, H.L., McKay, G.A. Measurement and data analysis, in: Gray, D.M., Male, D.M. (Eds.), Handbook of Snow: Principles, Processes, Management \& Use. Pergamon Press Canada Ltd., Toronto, pp. 91-274, 1981.

Goodison, B.E., Walker, A.E. Canadian development and use of snow cover information from passive microwave satellite data, in: Choudhury, B., Kerr, Y., Njoku, E., Pampaloni, P. (Eds.), Passive Microwave 
Remote Sensing of Land-Atmosphere Interactions, Utrecht, Netherlands, VSP BV, pp. 245-262, 1995.

Graybeal, D., Leathers, D. Snowmelt-related flood risk in Appalachia: first estimates from a historical snow climatology. Journal of Applied Meteorology and Climatology 45, 178-193, 2006.

Grody, N. Relationship between snow parameters and microwave satellite measurements: theory compared with AMSU observations from 23 to $150 \mathrm{GHz}$. Journal of Geophysical Research 113, D22108, 2008.

Grody, N.C., Basist, A.N. Global identification of snowcover using SSM/I measurements. IEEE Transactions on Geoscience and Remote Sensing 34 (1), 237-249, 1996.

Groisman, P.Y., Karl, T.R., Knight, R.W. Observed impact of snow cover on the heat balance and the rise of continental spring temperatures. Science 263, 199-200, 1994.

Grundstein, A., Mote, T., Leathers, D.J. A hybrid climatology of snow water equivalent over the northern Great Plains of the United States. Polar Geography 26 (3), 187-209, 2002.

Gutzler, D.S., Rosen, R.D. Interannual variability of wintertime snow cover across the Northern Hemisphere. Journal of Climate 5, 14411447, 1992.

Hall, D.K., Riggs, G.A. Accuracy assessment of the MODIS snow products. Hydrological Processes 21, 1534-1547, 2007.

Hall, D.K., Riggs, G.A., Salomonson, V.V. Development of methods for mapping global snow cover using moderate resolution imaging spectroradiometer data. Remote Sensing of Environment 54, 127140, 1995.

Hall, D.K., Kelly, R.E.J., Foster, J.L., Chang, A.T.C. Estimation of Snow Extent and Snow Properties, in: Anderson, M.G. (Ed.), Encyclopedia of Hydrological Sciences. Wiley, Berlin, pp. 811-829, 2005.

Hall, D.K., Riggs, G.A., Foster, J.L., Kumar, S.V. Development and evaluation of a cloud-gap-filled MODIS daily snow-cover product. Remote Sensing of Environment 114 (3), 496-503, 2010.

Hall, D.K., Riggs, G.A., Salomonson, V.V., DiGirolamo, N.E., Bayr, K.J. MODIS snow-cover products. Remote Sensing of Environment 83, 181-194, 2002.

Helfrich, S.R., McNamara, D., Ramsay, B.H., Baldwin, T., Kasheta, T. Enhancements to and forthcoming developments in the Interactive Multisensor Snow and Ice Mapping System (IMS). Hydrological Processes 21, 1576-1586, 2007.

Hinzman, L.D., Bettez, N.D., Bolton, W.R., Chapin, F.S., Dyurgerov, M.B., Fastie, C., Griffith, B., Hollister, R.D., Hope, A., Huntington, H.P., Jensen, A.M., Jia, G.J., Jorgenson, T., Kane, D., Klein, D.R., Kofinas, G., Lynch, A.H., Lloyd, A.H., xMcGuire, A.H., Nelson, F.E., Oechel, W.C., Osterkamp, T.E., Racine, C., Romanovsky, V.E., Stone, R.S., Stow, D.A., Sturm, M., Tweedie, C., Vourlitis, G.L., Walker, M.D., Walker, D.A., Webber, P.J., Welker, J.M., Winker, K.S., Yoshikawa, K. Evidence and implications of recent climate change in northern Alaska and other arctic regions. Climatic Change 72, 251-298, 2005.

IPCC. Climate Change 2007: The Physical Science Basis. Contribution of Working Group I to the Fourth Assessment Report of the Intergovernmental Panel on Climate Change, in: S.D. Soloman et al., Intergovernmental Panel on Climate Change. Cambridge University Press.

Jones, H.G., Pomeroy, J.W., Walker, D.A., Hoham, R.W. Snow Ecology: An Interdisciplinary Examination of Snow-Covered Ecosystems. Cambridge University Press, UK, Cambridge, 2001.

Jordan, R. A one-dimensional temperature model for a snow cover: technical documentation for SNTHERM.89. US Army Corps of Engineers, Cold Regions Research and Engineering Laboratory, Hanover, NH, 1991.

Jordan, R.E., Albert, m.R., Brun, E. Physical properties within the snow cover and their parameterization, in: Armstrong, R.A., Brun, E. (Eds.), Snow and Climate: Physical Processes, Surface Energy Exchange and Modeling. Cambridge University Press, Cambridge, UK, p. p. 22, 2008.
Kelly, R.E.J. The AMSR-E snow depth algorithm: description and initial results. Journal of the Remote Sensing Society of Japan 29 (1), 307317, 2009.

Kelly, R.E.J., Chang, A.T.C., Tsang, L., Foster, J.L. Development of a prototype AMSR-E global snow area and depth algorithm. IEEE Transactions on Geoscience and Remote Sensing 41 (2), 230-242, 2003.

Kelly, R.E.J., Chang, A.T.C., Foster, J.L., Hall, D.K. Using remote sensing and spatial models to monitor snow depth and snow water equivalent, in: Kelly, R.E.J., Drake, N.A., Barr, S.L. (Eds.), Spatial Modeling of the Terrestrial Environment. John Wiley and Sons, Ltd., Chichester, England, pp. 5-57, 2004.

Kinar, N.J., Pomeroy, J.W. Determining snow water equivalent by acoustic sounding. Hydrological Processes 21 (19), 2623-2640, 2007.

Klein, A.G., Stroeve, J. Development and validation of a snow albedo algorithm for the MODIS instrument. Annals of Glaciology 34, 45-52, 2002.

Klein, A.G., Hall, D.K., Riggs, G.A. Improving snow cover mapping in forests through the use of a canopy reflectance model. Hydrological Processes 12, 1723-1744, 1998.

Langham, E.J. Physics and properties of snow cover, in: Gray, D.M., Male, D.M. (Eds.), Handbook of Snow: Principles, Processes, Management \& Use. Pergamon Press Canada Ltd., Toronto, pp. 275-337, 1981.

Lawrence, D.M., Slater, A.G. A projection of severe near-surface permafrost degradation during the 21 st century. Geophysical Research Letters 32 (L24401), doi:10.1029/2005GL025080, 2005.

Leathers, D.J., Robinson, D.A. The association between extremes in North American snow cover extent and United States temperature. Journal of Climate 6, 1345-1355, 1993.

Leathers, D.J., Kluck, D.R., Kroczynski, S. The severe flooding event of January 1996 across north central Pennsylvania. Bulletin of the American Meteorological Society 79 (5), 785-797, 1998.

Lenton, T.M., Held, H., Kriegler, E., Hall, J.W., Lucht, W., Rahmstorf, S., Schellnhuber, H.J. Tipping elements in the Earth's climate system. Proceedings of the National Academy of Sciences 105 (6), 1786-1796, 2008.

MacKay, M.D., Bartlett, P.A., Chan, E., Derksen, C., Guo, S., Leighton, $\mathrm{H}$. On the simulation of regional scale sublimation over boreal and agricultural landscapes in a climate model. Atmosphere-Ocean 44 (3), 289-304, 2006.

Markus, T., Powell, D.C., Wang, J.R. Sensitivity of passive microwave snow depth retrievals to weather effects and snow evolution. IEEE Transactions on Geoscience and Remote Sensing 44 (1), 68-77, 2006.

Matson, M., Wiesnet, D.R. New data base for climate studies. Nature 289, 451-456, 1981.

Matzler, C. Passive microwave signatures of landscapes in winter. Meteorological and Atmospheric Physics 54, 241-260, 1994.

Metsamaki, S.J., Anttila, S.T., Markus, H.J., Vepsalainen, J.M. A feasible method for fractional snow cover mapping in boreal zone based on a reflectance model. Remote Sensing of Environment 95, 77-95, 2005.

Mialon, A., Fily, M., Royer, A. Seasonal snow cover extent from microwave remote sensing data: comparison with existing ground and satellite based measurements, in: European Association of Remote Sensing Laboratories (EARSeL), Strasbourg, France, pp. 215-225, 2005.

Miller, J.R., Russell, G.L. Projected impact of climate change on the freshwater and salt budgets of the Arctic Ocean by a global climate model. Geophysical Research Letters 27 (8), 1183-1186, 2000.

Mote, P.W. Climate-driven variability and trends in mountain snowpack in western North America. Journal of Climate 19, 6209-6220, 2006.

Mote, P.W., Hamlet, A.F., Clark, M.P., Lettenmaier, D.P. Declining mountain snowpack in western North America. Bulletin of the American Meteorological Society 86 (1), 39-49, 2005.

Mote, T.L. On the role of snow cover in depressing air temperature. Journal of Applied Meteorology and Climatology 47, 2008-2022, 2008 . 
Mote, T.L., Grundstein, A.J., Leathers, D.J., Robinson, D.A. A comparison of modeled, remotely sensed, and measured snow water equivalent in the northern Great Plains. Journal of Applied Meteorology 43, 1887-1898, 2003.

Nghiem, S.V., Steffen, K., Kwok, R., Tsai, W.Y. Detection of snowmelt regions on the Greenland ice sheet using diurnal backscatter change. Journal of Glaciology 47 (159), 539-547, 2001.

Nolin, A.W. Towards retrieval of forest cover density over snow from the Multi-angle Imaging SpectroRadiometer (MISR). Hydrological Processes 18, 3623-3636, 2004.

Nolin, A.W. Recent advances in remote sensing of seasonal snow. Journal of Glaciology 56 (200), 1141-1150, 2010.

Nolin, A.W., Dozier, J. A hyperspectral method for remotely sensing the grain size of snow. Remote Sensing of Environment 74 (2), 207-216, 2000.

Nolin, A.W., Daly, C. Mapping "at-risk" snow in the Pacific Northwest, USA. Journal of Hydrometeorology 7, 1166-1173, 2006.

Painter, T.H., Dozier, J. The effect of anisotropic reflectance on imaging spectroscopy of snow properties. Remote Sensing of Environment 89, 409-422, 2004.

Painter, T.H., Dozier, J., Roberts, D.A., Davis, R.E., Green, R.O. Retrieval of subpixel snow-covered area and grain size from imaging spectrometer. Remote Sensing of Environment 85, 64-77, 2003.

Painter, T.H., Rittger, K., McKenzie, C., Slaughter, P., Davis, R.E., Dozier, J. Retrieval of subpixel snow covered area, grain size, and albedo from MODIS. Remote Sensing of Environment 113, 868-879, 2009.

Parajka, J., Bloschl, G. Spatio-temporal combination of MODIS images potential for snow cover mapping. Water Resources Research 44, W03406, 2008

Peterson, B., Holmes, J.R.M., McClelland, J.W., Vorosmarty, C.J., Lammers, R.B., Shiklomanov, A.I., Shiklomanov, I.A., Rahmstorf, S. Increasing river discharge to the Arctic Ocean. Science 298 (5601), 2171-2173, 2002.

Pulliainen, J. Mapping of snow water equivalent and snow depth in boreal and sub-Arctic zones by assimilating space-borne microwave radiometer data and ground-based observations. Remote Sensing of Environment 101 (2), 257-269, 2006.

Pulliainen, J. Overview on GlobSnow Project: key questions to be resolved (coverage, aggregation, validation, towards a future ECV), in: The 1st ESA DUE GlobSnow User Workshop, Innsbruck, Austria, 2010.

Pulliainen, J., Hallikainen, M. Retrieval of regional snow water equivalent from space-borne passive microwave observations. Remote Sensing of Environment 75 (1), 76-85, 2001.

Rahmstorf, S. The thermohaline ocean circulation: a system with dangerous thresholds? Climatic Change 46 (3), 247-256, 2000.

Raisanen, J. Warmer climates: less or more snow? Climate Dynamics 30, 307-319, 2007.

Ramsay, B.H. The interactive multisensor snow and ice mapping system. Hydrological Processes 12, 1537-1546, 1998.

Ramsay, B.H. Prospects for the Interactive Multisensor Snow and Ice Mapping System (IMS), in: 57th Eastern Snow Conference, Syracuse, New York, USA, 2000.

Rango, A., Walker, A.E., Goodison, B.E. Snow and ice, in: Schultz, G.A., Engman, E.T. (Eds.), Remote Sensing in Hydrology and Water Management. Springer, Berlin, pp. 39-262, 2000.

Rawlins, M., Steele, M., Holland, M., Adam, J.C., Cherry, J., Francis, J.A., Groisman, P.Y., Hinzman, L.D., Huntington, T.G., Kane, D., Kimball, J., Kwok, R., Lammers, R.B., Lee, C., Lettenmaier, D.P., McDonald, K., Podest, E., Pundsack, J., Rudels, B., Serreze, M.C., Shiklomanov, A.I., Skagseth, O., Troy, T., Vorosmarty, C.J., Wensnahan, M., Wood, E., Woodgate, R., Yang, D., Zhang, K., Zhang, T. Analysis of the Arctic system for freshwater cycle intensification: observations and expectations. Journal of Climate 23, 5715-5737, 2010.

Rees, A., Derksen, C., English, M., Walker, A., Duguay, C. Uncertainty in snow mass retrievals from satellite passive microwave data in lake- rich high-latitude environments. Hydrological Processes 20, 1019 1022, 2006.

Rennermalm, A.K., Wood, E.F., Weaver, A.J., Eby, M., Dery, S.J. Relative sensitivity of the Atlantic meridional overturning circulation to river discharge into Hudson Bay and the Arctic Ocean. Journal of Geophysical Research 112 (G04S48), 2007.

Riggs, G.A., Hall, D.K. Reduction of Cloud Obscuration in the MODIS Snow Data Product, in: Eastern Snow Conference, Stowe, Vermont, pp. 205-212, 2002.

Riggs, G.A., Hall, D.K. MODIS Snow cover Algorithms and Products Plans for Next Version, in: 68th Annual Eastern Snow Conference, Montreal, QC, Canada, in press.

Riggs, G.A., Digirolamo, N., Hall, D.K. Comparison of MODIS daily global fractional snow cover maps at 0.05 - and 0.25-Degree resolutions, in: 62nd Eastern Snow Conference, Waterloo, ON, Canada, pp. 21-27, 2005.

Riggs, G.A., Hall, D.K., Salomonson, V.V. "MODIS Snow Products Users' Guide", 2006. Available from: $<$ http://modis-snow-ice.gsfc.nasa.gov/sugkc2.html>

Robinson, D., Kukla, G. Maximum surface albedo of seasonally snow covered lands in the Northern Hemisphere. Journal of Climate and Applied Meteorology 24, 402-411, 1985.

Robinson, D.A., Frei, A. Seasonal variability of Northern Hemisphere snow extent using visible satellite data. Professional Geographer 52 (2), 307-315, 2000.

Robinson, D.A., Estilow, T. A Northern Hemisphere Snow Extent Climate Data Record, in: Fall Meeting of the American Geophysical Union, San Francisco, CA, 2008.

Robinson, D.A., Dewey, K.F., Heim, R.R.J. Global snow cover monitoring: an update. Bulletin of the American Meteorological Society 74 (9), 1689-1696, 1993.

Robinson, D.A., Tarpley, J.D., Ramsay, B.H. Transition from NOAA weekly to daily hemispheric snow charts, in: 10th Symposium on Global Change Studies, Dallas, TX. American Meteorological Society, 1999.

Roesch, A., Gilgen, H., Ohmura, A. Assessment of GCM simulated snow albedo using direct observations. Climate Dynamics 15 (6), 405, 1999.

Romanov, P., Gutman, G., Csiszar, I. Satellite-derived snow cover maps for North America: accuracy assessment. Advances in Space Research 30 (11), 2455-2460, 2002.

Romanov, P., Tarpley, D., Gutman, G., Carroll, T. Mapping and monitoring of the snow cover fraction over North America. Journal of Geophysical Research 108 (D16), 2003.

Romanovsky, V.E., Smith, S.L., Christiansen, H.H. Permafrost thermal state in the Polar Northern Hemisphere during the International Polar Year 2007-2009: a synthesis. Permafrost and Periglacial Processes 21, 106-116, 2010.

Salomonson, V.V., Appel, I. Estimating fractional snow coverage from MODIS using the Normalized Difference Snow Index (NDSI). Remote Sensing of Environment 89, 351-360, 2004.

Salomonson, V.V., Appel, I. Development of the Aqua MODIS NDSI fractional snow cover algorithm and validation studies. IEEE Transactions on Geoscience and Remote Sensing 44 (7), 1747-1756, 2006.

Savoie, M.H., Wang, J., Brodzik, M.J., Armstrong, R.L. Improved Snow Cover Retrievals from Satellite Passive Microwave Data over the Tibet Plateau: the Need for Atmospheric Corrections over High Elevations (Poster), in: American Geophysical Union, Fall Meeting Supplement Abstract C23A-0942, 2007.

Savoie, M.H., Armstrong, R.A., Brodzik, M.J., Wang, J.R. Atmospheric corrections for improved satellite passive microwave snow cover retrievals over the Tibet Plateau. Remote Sensing of Environment 113, 2661-2669, 2009.

Schanda, E., Matzler, C., Kunzi, K. Microwave remote sensing of snow cover. International Journal of Remote Sensing 4, 149-158, 1983.

Scherer, D., Hall, D.K., Hochschild, V., Konig, M., Winther, J.-G., Duguay, C.R., Pivot, F., Matzler, C., Rau, F., Seidel, K., Solberg, R., Walker, A.E. Remote Sensing of Snow. Remote Sensing in Northern 
Hydrology: Measuring Environmental Change, C. R. a. P. Duguay, Alain, Washington, DC. American Geophysical Union, p. 163, 2005.

Schmugge, T.J., Kustas, W.P., Ritchie, J.C., Jackson, T.J., Rango, A. Remote sensing in hydrology. Advances in Water Resources 25, 1367 1385, 2002.

Schuur, E.A.G., Bockheim, J., Canadell, J.G., Euskirchen, E., Field, C.B., Goryachkin, S.V., Hagemann, S., Kuhry, P., Lafleur, P.M., Lee, H., Mazhitova, G., Nelson, F.E., Rinke, A., Romanovsky, V.E., Shiklomanov, N., Tarnocai, C., Venevsky, S., Vogel, J.G., Zimov, S.A. Vulnerability of permafrost carbon to climate change: implications for the global carbon cycle. Bioscience 58 (8), 701-714, 2008.

Siljamo, N., Hyvarinen, O. New geostationary satellite-based snow-cover algorithm. Journal of Applied Meteorology and Climatology 50, 12751290, 2011.

Sturm, M., Holmgren, J., Liston, G.E. A seasonal snow cover classification system for local to global applications. Journal of Climate 8 (5), 1261-1283, 1995.

Tait, A. Estimation of snow water equivalent using passive microwave radiation data. Remote Sensing of Environment 64, 286-291, 1998.

Tait, A., Armstrong, R. Evaluation of SMMR satellite-derived snow depth using ground-based measurements. International Journal of Remote Sensing 17 (4), 657-665, 1996.

Tait, A.B., Hall, D.K., Foster, J.L., Armstrong, R.L. Utilizing multiple datasets for snow-cover mapping. Remote Sensing of Environment 72, 111-126, 2000.

Takala, M., Luojus, K., Pulliainen, J., Derksen, C., Lemmetyinen, J., Karna, J.-P., Koskinen, J., Bojkov, B. Estimating Northern Hemisphere snow water equivalent for climate research through assimilation of space-borne radiometer data and ground-based measurements. Remote Sensing of Environment 115, 3517-3529, 2011.

Tedesco, M., Kim, E.J. Inter-comparison of electromagnetic models for passive microwave remote sensing of snow. IEEE TGARS Special Issue 'IGARSS 2005' 44 (10), 2654-2666, 2006.

Tedesco, M., Miller, J. Observations and statistical analysis of combined active-passive microwave space-borne data and snow depth at large spatial scales. Remote Sensing of Environment 111 (2-3), 382-397, $2007 \mathrm{a}$.

Tedesco, M., Miller, J. Northern Hemisphere snow-covered area mapping: optical versus active and passive microwave data. IEEE Geoscience and Remote Sensing Letters 4 (2), 221-225, 2007b.

Tedesco, M., Narvekar Assessment of the NASA AMSR-E SWE product. IEEE Journal of Selected Topics in Applied Earth Observations and Remote Sensing 3 (1), 141-159, 2010.

Tedesco, M., Kim, E.J., Gasiewski, A., Stankov, B. Analysis of multi-scale radiometric data collected during the Cold Land Processes Experiment-1 (CLPX-1). Geophysical Research Letters 32 (L18501), 4, 2005.
Tedesco, M., Kelly, R.E.J., Foster, J.L., Chang, A.T.C. AMSR-E/Aqua Daily L3 Global Snow Water Equivalent EASE-Grids V002, National Snow and Ice Data Center Digital Media, Boulder Colorado, USA, 2011.

Tedesco, M., Pullianinen, J., Takala, M., Hallikainen, M., Pampaloni, P. Artificial neural network-based techniques for the retrieval of SWE and snow depth from SSM/I data. Remote Sensing of Environment 90 (1), 76-85, 2004.

Todhunter, P.E. A hydroclimatological analysis of the Red River of the North snowmelt flood catastrophe of 1997. Journal of the American Water Resources Association 37 (5), 1263-1278, 2001.

Tong, J., Velicogna, I. A comparison of AMSR-E/Aqua snow products with in situ observations and MODIS snow cover products in the Mackenzie River Basin, Canada. Remote Sensing 2, 2313-2322, 2010 .

Tong, J., Dery, S.J., Jackson, P.L., Derksen, C. Testing snow water equivalent retrieval algorithms for passive microwave remote sensing in an alpine watershed of western Canada. Canadian Journal of Remote Sensing 36 (Supplement 1), S74-S86, 2010a.

Tong, J., Dery, S.J., Jackson, P.L., Derksen, C. Snow distribution from SSM/I and its relationships to the hydroclimatology of the Mackenzie River Basin, Canada. Advances in Water Resources 33 (6), 667-677, 2010b.

Ulaby, F.T., Stiles, W.H. The active and passive microwave response to snow parameters 2. Water equivalent of dry snow. Journal of Geophysical Research 85 (C2), 1045-1049, 1980.

Walsh, J.E. Snow cover and atmospheric variability. American Scientist 72, 50-57, 1984.

Wang, J.R., Tedesco, M. Identification of atmospheric influences on the estimation of snow water equivalent from AMSR-E measurements. Remote Sensing of Environment 111 (2-3), 398-408, 2007.

Wang, L., Derksen, C., Brown, R. Detection of pan-Arctic terrestrial snowmelt from QuikSCAT, 2000-2005. Remote Sensing of Environment 112 (10), 3794-3805, 2008.

Ye, H., Mather, J.R. Polar snow cover changes and global warming. International Journal of Climatology 17, 155-162, 1997.

Ye, H., Cho, H.-R., Gustafson, P.E. The changes in Russian winter snow accumulation during 1936-83 and its spatial patterns. Journal of Climate 11, 856-863, 1998.

Zhang, T. Influence of the seasonal snow cover on the ground thermal regime: an overview. Reviews of Geophysics 43, RG2003, 2005.

Zhang, X., Zwiers, F.W., Hegerl, G.C., Lambert, F.H., Gillett, N.P., Soloman, S., Stott, P.A., Nozawa, T. Detection of human influence on 20th-century precipitation trends. Nature 448, 461-466, 2007. 